\title{
Thermodynamic assessment of non-catalytic Ceria for syngas production by methane reduction and $\mathrm{CO}_{2}+\mathrm{H}_{2} \mathrm{O}$ oxidation
}

\author{
Archishman Bose $^{1,2} \cdot$ Azharuddin Farooqui $^{1,3} \cdot$ Domenico Ferrero $^{1} \cdot$ Massimo Santarelli $^{1} \cdot$ Jordi Llorca $^{3}$
}

Received: 19 October 2018 / Accepted: 21 January 2019 / Published online: 31 January 2019

(c) The Author(s) 2019

\begin{abstract}
Chemical looping syngas production is a two-step redox cycle with oxygen carriers (metal oxides) circulating between two interconnected reactors. In this paper, the performance of pure $\mathrm{CeO}_{2} / \mathrm{Ce}_{2} \mathrm{O}_{3}$ redox pair was investigated for low-temperature syngas production via methane reduction together with identification of optimal ideal operating conditions. Comprehensive thermodynamic analysis for methane reduction and water and $\mathrm{CO}_{2}$ splitting was performed through process simulation by Gibbs free energy minimization in ASPEN Plus ${ }^{\circledR}$. The reduction reactor was studied by varying the $\mathrm{CH}_{4} / \mathrm{CeO}_{2}$ molar ratio between 0.4 and 4 along with the temperature from 500 to $1000{ }^{\circ} \mathrm{C}$. In the oxidation reactor, steam and carbon dioxide mixture oxidized the reduced metal back to $\mathrm{CeO}_{2}$, while producing simultaneous streams of $\mathrm{CO}$ and $\mathrm{H}_{2}$ respectively. Within the oxidation reactor, the flow and composition of the mixture gas were varied, together with reactor temperature between 500 and $1000{ }^{\circ} \mathrm{C}$. The results indicate that the maximum $\mathrm{CH}_{4}$ conversion in the reduction reactor is achieved between 900 and $950{ }^{\circ} \mathrm{C}$ with $\mathrm{CH}_{4} / \mathrm{CeO}_{2}$ ratio of $0.7-0.8$, while, for the oxidation reactor, the optimal condition can vary between 600 and $900{ }^{\circ} \mathrm{C}$ based on the requirement of the final product output $\left(\mathrm{H}_{2} / \mathrm{CO}\right)$. The system efficiency was around $62 \%$ for isothermal operations at $900{ }^{\circ} \mathrm{C}$ and complete redox reaction of the metal oxide.
\end{abstract}

Keywords Oxygen carriers $\cdot$ Ceria $\cdot$ Chemical looping $\cdot$ Syngas $\cdot$ Thermodynamic analysis

\section{Introduction}

Synthesis of non-fossil fuels through carbon dioxide $\left(\mathrm{CO}_{2}\right)$ recycling via thermochemical or electrochemical pathways has received significant research interest in recent years as a complementary option to mitigate carbon emissions [2, $6,13,30]$. Thermochemical redox cycles driven by concentrated solar power (CSP) have been widely studied for simultaneous splitting of $\mathrm{H}_{2} \mathrm{O}$ and $\mathrm{CO}_{2}$ for syngas (a mixture

Archishman Bose

archishman.bose@ucc.ie

1 Energy Department (DENERG), Politecnico di Torino, Corso Duca degli Abruzzi 24, Turin 10129, Italy

2 Marine and Renewable Energy Research (MaREI) Centre, Environmental Research Institute, School of Engineering and Food Science, University College Cork, Lee Road, Cork T23 XE10, Ireland

3 Institute of Energy Technologies, Department of Chemical Engineering, Barcelona Research Center in Multiscale Science and Engineering, Universitat Politècnica de Catalunya, EEBE, Eduard Maristany 10-14, Barcelona 08019, Spain of $\mathrm{H}_{2}$ and $\mathrm{CO}$ ) production [43, 44, 50], which can be further processed to valuable compounds via established industrial processes like the Fischer-Tropsch process. Of the numerous multi-step thermochemical redox cycles that have been proposed, the two-step metal-oxide redox pair systems have shown considerable potential for synthetic solar fuel generation $[40,49,55]$. These thermochemical cycles utilize the transition between a higher valence oxidized $\left(\mathrm{MeO}_{\text {oxd }}\right)$ and lower valence reduced $\left(\mathrm{MeO}_{\text {red }}\right)$ form of a metal-oxide usually having multiple oxidation states [2]. At first, $\mathrm{MeO}_{\text {oxd }}$ undergoes a highly irreversible and endothermic thermal reduction (TR), thereby releasing oxygen and generating $\mathrm{MeO}_{\text {red }}$. Subsequently, $\mathrm{MeO}_{\text {red }}$ is oxidized back to a higher valence state by taking oxygen from water and/or $\mathrm{CO}_{2}$ (often present in industrial effluent gases, viz., oxyfuel power plant exhausts) via an exothermic reaction, in turn, generating $\mathrm{H}_{2}$ and $\mathrm{CO}$ in water splitting (WS) and $\mathrm{CO}_{2}$ splitting (CDS) reactions, respectively. This results in the reduction temperature $\left(T_{\mathrm{RED}}\right)$ to be much higher (often above $1400{ }^{\circ} \mathrm{C}$ ) than the oxidation temperature ( $\left.T_{\mathrm{OXI}}\right)$ [3]. In a solar-driven cycle, this highly endothermic reduction reaction is sustained by concentrated solar power, for which multiple solar reactor 
types have been investigated. Packed beds reactors [52], porous structures $[8,19]$, rotating components $[15,29]$ and moving particles $[41,56]$ are some common examples of such reactors.

The oxygen released during reduction depends not only on the metal cation and its corresponding valence state but also on the possible reduction extent. Highest possible dissociations are sought in principle to maximize the oxygen release and uptake during reduction and oxidation, respectively, leading to higher $\mathrm{H}_{2}$ and $\mathrm{CO}$ yields per mass of redox material used in the cycle $[3,33,41,46,58]$. Since the cycle efficiency is defined essentially as the heating value of the fuel produced in comparison to the energy input, it would thus be increased as well. Typical redox pairs studied include metal oxide/metal systems (such as $\mathrm{ZnO} / \mathrm{Zn} ; \mathrm{SnO} / \mathrm{Sn}$ ) or metal oxide/metal oxide systems $\left(\mathrm{Fe}_{3} \mathrm{O}_{4} / \mathrm{FeO} ; \mathrm{Mn}_{3} \mathrm{O}_{4} / \mathrm{MnO}\right.$; $\mathrm{CeO}_{2} / \mathrm{Ce}_{2} \mathrm{O}_{3}$, etc.) [46] that can also be classified into volatile and non-volatile redox pairs. Other metals oxides tested for chemical looping also include ferrites with different valences, $\mathrm{Co}_{3} \mathrm{O}_{4}, \mathrm{Nb}_{2} \mathrm{O}_{5}, \mathrm{WO}_{3}, \mathrm{SiO}_{2}, \mathrm{In}_{2} \mathrm{O}_{3}, \mathrm{CdO}$ to name few [18, 21, 22, 25, 48] (Fig. 1).

An intriguing approach to operate the cycle at a lower temperature, thereby decreasing the temperature swing between reduction and oxidation, is to combine the redox cycle with the methane reforming according to the Eqs. (1)-(2) [27, 37, 38, 57]. As an added benefit, parallel streams of syngas from both the reduction and the oxidation reactors are generated as shown in Fig. 2. In fact, by tuning opportunely the operation conditions of the reactor, the syngas streams can reach an $\mathrm{H}_{2}$ : $\mathrm{CO}$ ratio of 2:1, ideal to produce methanol, or liquid fuel via the Fischer-Tropsch process:

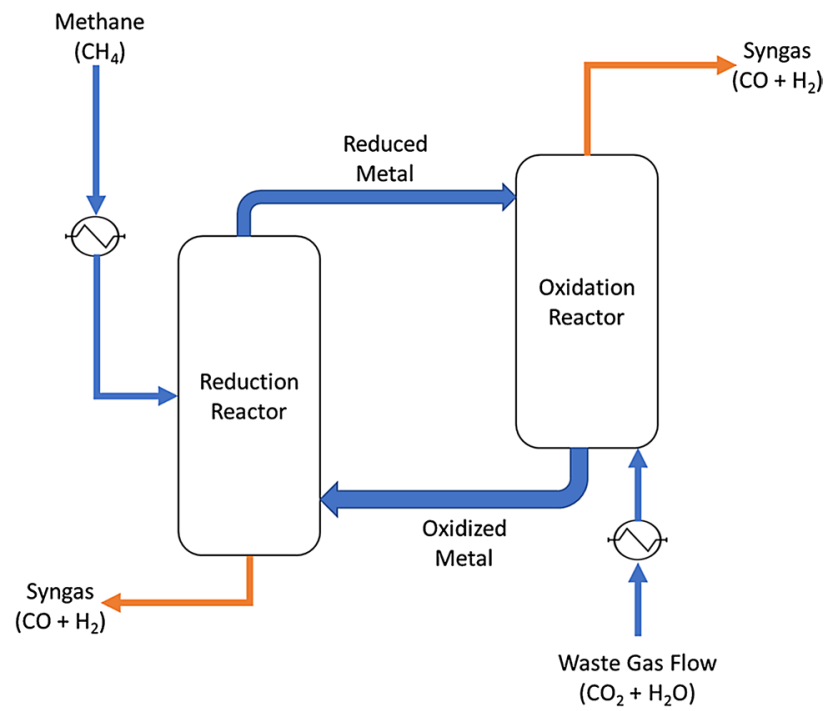

Fig. 1 Conceptual scheme of the chemical looping Syngas production through methane reduction and corresponding splitting of water and carbon dioxide
Methane-reduction : $\mathrm{MeO}_{x}+\delta \mathrm{CH}_{4} \rightarrow \mathrm{MeO}_{x-\delta}+\delta\left(\mathrm{CO}+2 \mathrm{H}_{2}\right)$

Water-splitting (WS) : $\mathrm{MeO}_{x-\delta}+\delta \mathrm{H}_{2} \mathrm{O} \rightarrow \mathrm{MeO}_{\mathrm{x}}+\delta \mathrm{H}_{2}$

$\mathrm{CO}_{2}$-splitting (CDS): $\mathrm{MeO}_{x-\delta}+\delta \mathrm{CO}_{2} \rightarrow \mathrm{MeO}_{\mathrm{x}}+\delta \mathrm{CO}$

During reduction (Eq. 1), the metal oxide is reduced by methane, often up to a non-stoichiometric extent, $\delta$. The $\delta$ moles of oxygen thus released, form $\mathrm{CO}$ and $\mathrm{H}_{2}$ by partial oxidation of $\mathrm{CH}_{4}$. In the subsequent reaction steps, (Eq. 2), $\mathrm{MeO}_{\mathrm{x}-\delta}$ reacts with $\mathrm{CO}_{2}$ and/or $\mathrm{H}_{2} \mathrm{O}$ to reincorporate oxygen into the metal oxide lattice, while reducing the $\mathrm{CO}_{2}$ and/or $\mathrm{H}_{2} \mathrm{O}$ into a $\mathrm{CO}$ or $\mathrm{H}_{2}$, respectively. Reactions (2a) and $(2 b)$ can be intrinsically assumed to result in complete oxidation at thermodynamically favourable temperatures depending on the metal oxide redox pairs.

Cerium (IV) oxide $\left(\mathrm{CeO}_{2}\right)$ is widely investigated in literature for its structural, chemical and optical properties, making it a promising material in several fields of applications, such as fuel cells, catalysis, $\mathrm{CO}_{2}$ adsorbing materials, nanofluids, etc. [32]. Furthermore, the crystallographic stability of $\mathrm{CeO}_{2}$, even after several runs of thermal processes, is well documented [1,9]. Ceria has received particular attention in the context of solardriven thermochemical production of fuels due to large oxygen content capacity and ability to accept and release in response to temperature and oxygen chemical potential change. Higher efficiency can be achieved by structuring ceria in mesoporous or microporous forms to achieve relatively short bulk diffusion lengths, high surface area and increased porosity for easy transport of product and reactant gases. It is observed that the large porosity is desired for higher radiative heat transfer [11,24]. In recent studies $[12,23]$ it has been concluded that in the redox cycle, at temperatures above $1000{ }^{\circ} \mathrm{C}$, due to the extremely rapid bulk oxygen diffusion and surface reaction on ceria, the overall rate depends primarily on the reactant gas flow rate. This is usually the limiting phenomenon referred as gas phase limited dynamics (thermo-kinetic controlled) or quasi-equilibrium behaviour, for reduction. For lower temperature (below $1000^{\circ} \mathrm{C}$ ) or in the oxidation step, the surface reaction on the porous ceria is the rate-limiting step. This rapid kinetics, together with minimal effect of sintering at high temperature (below $1500{ }^{\circ} \mathrm{C}$ ) $[47,51$, 59] with good attrition resistance and mechanical strength makes ceria the state of the art among the non-volatile redox pairs for $\mathrm{CO}_{2} / \mathrm{H}_{2} \mathrm{O}$ splitting application [57], which can be further exploited for large-scale applications [4]. Even though numerous studies have focused on non-stoichiometric ceria, the complete reduction of $\mathrm{CeO}_{2}$ to $\mathrm{Ce}_{2} \mathrm{O}_{3}$ 
( $\delta=0.5)$ is required for a high $\mathrm{H}_{2}$ and $\mathrm{CO}$ yield, primarily constrained by the temperature. The complete thermal reduction to $\mathrm{Ce}_{2} \mathrm{O}_{3}$ requires more than $2000{ }^{\circ} \mathrm{C}$, rarely achievable even by CSP systems for continuous operation. In contrast, fuel reduction would assist the metal oxide to be reduced at a much lower temperature allowing the redox cycle to operate isothermally, as well as continuously. With the abundance and low price of natural gas, or the use of biomethane as a renewable fuel, reactive chemical looping partial oxidation of methane together with $\mathrm{CO}_{2}$ and $\mathrm{H}_{2} \mathrm{O}$ dissociation offers a simple and promising multistep syngas production process. In effect, such an isothermal redox operation would then lead to a much reduced operation cost, enhanced stability and improved system efficiency due to the elimination of inefficient processes.

Nonetheless, most of the early propositions and experiments of the novel methodology has been performed considering catalytic processes, which, even though would enhance the rate of reaction, often increase the operation costs by using expensive catalysts like Platinum or Rhenium [17, 38]. Hence, the use of non-catalytic ceria is much desired from both technical and commercial significance. In this paper, the thermodynamic limitations of the non-catalytic process, aimed at establishing the theoretical limits of the redox cycle with non-catalytic ceria as the oxygen carrier and methane reduction have been studied and documented.

\section{Thermodynamic considerations}

Unlike iron oxide, which has received wide attention for thermodynamic analysis for redox chemical looping cycles $[14,39,40]$, that for ceria is limited in literature, especially for methane reduction. Bader et al. [5] reported a thermodynamic analysis of isothermal redox cycling of ceria at $1500{ }^{\circ} \mathrm{C}$, achieving efficiencies of up to $10 \%$ and $18 \%$ for hydrogen and carbon monoxide production, respectively. The efficiencies were considerably improved to over $30 \%$ for hydrogen production by introducing a temperature swing of $150{ }^{\circ} \mathrm{C}$ between the reduction and the oxidation reactors. A similar investigation for non-stoichiometric ceria cycle by Furler et al. [19] in a thermally driven cycle reported much lower solar-to-fuel energy conversion efficiency of $1.73 \%$ using sweep inert gas, the peak achieved as $3.53 \%$. The lower efficiencies are due to no pressure swing between the two steps. In order to improve the system with respect to the scale and efficiency, a moving packed bed of reactive particle reactors have been employed to investigate and analyse the efficiency [16]. Indeed, the scope for increasing the energy efficiency through multiple processes including heat recovery was suggested, enabling the conversion efficiency of solar energy into $\mathrm{H}_{2}$ and $\mathrm{CO}$ at the design point to exceed
$30 \%$. It is worth mentioning that non-stoichiometry $(\delta)$ never reaches 0.5 for thermal reduction without changing its fluorite-related structure having $\alpha$-phase below $0.286(1.714 \leq(2-\delta) \leq 2.0)$ at $1000^{\circ} \mathrm{C}[9,31,35]$. Similarly, with methane reduction, a $\delta$ of 0.378 was reported at $1000{ }^{\circ} \mathrm{C}$ [7], while Warren et al. reported a $\delta$ of 0.21 at $1035^{\circ} \mathrm{C}$ by [53]. But the same group conducted TGA experiments of ceria with methane reduction and reported a $\delta$ of 0.5 above $900{ }^{\circ} \mathrm{C}$ by using Pt crucible instead of alumina [54], highlighting the $\mathrm{CeO}_{2} / \mathrm{Ce}_{2} \mathrm{O}_{3}$ redox behaviour during fuel reduction. Similar claims of achieving $\mathrm{CeO}_{2} / \mathrm{Ce}_{2} \mathrm{O}_{3}$ redox cycles were reported for solar methane reforming and $\mathrm{H}_{2} \mathrm{O} / \mathrm{CO}_{2}$ splitting in a solar thermogravimetric device specially designed for particular experiments [36], wherein after each redox cycle the crystalline phase is regained. Therefore, the $\mathrm{CeO}_{2} / \mathrm{Ce}_{2} \mathrm{O}_{3}$ redox pair is selected in the present study to evaluate the thermodynamic constraints of methane-driven cycle as described by Eqs. (3), (4):

Methane reduction: $2 \mathrm{CeO}_{2}+\mathrm{CH}_{4} \rightarrow \mathrm{Ce}_{2} \mathrm{O}_{3}+\mathrm{CO}+2 \mathrm{H}_{2}$

Water - splitting (WS): $\mathrm{Ce}_{2} \mathrm{O}_{3}+\mathrm{H}_{2} \mathrm{O} \rightarrow 2 \mathrm{CeO}_{2}+\mathrm{H}_{2}$

$\mathrm{CO}_{2}$ - splitting (CDS): $\mathrm{Ce}_{2} \mathrm{O}_{3}+\mathrm{CO}_{2} \rightarrow 2 \mathrm{CeO}_{2}+\mathrm{CO}$

In the reduction reactor, the methane reduces the metal oxide at a higher oxidation state $\left(\mathrm{CeO}_{2}\right)$ to a lower oxidation state $\left(\mathrm{Ce}_{2} \mathrm{O}_{3}\right)$, while itself being oxidized to $\mathrm{CO}$ and $\mathrm{H}_{2}$ via reaction (3). The reduced ceria oxide is then recycled back to the higher oxidation state through reactions (4a) and (4b). In both the reactors, syngas can be generated, however, with varying $\mathrm{H}_{2} / \mathrm{CO}$ fractions. While, from thermodynamic and mass conservation conditions, the $\mathrm{H}_{2}$ to $\mathrm{CO}$ ratio of the syngas from the reduction reactor is always $2: 1$, the ratio in the oxidation reactor can be varied based on the inlet gas feed mixture and other thermodynamic parameters.

Multiple studies, mostly based on iron oxide-based redox metal pairs have reported the conversion efficiencies and operating conditions for conversion of methane into syngas over metal oxides [26, 34, 45]. Such studies also include the limiting operation range based on the need to prevent carbon deposition reactions as crucial for the system operation. Thermodynamics of Ceria reduction with hydrogen have been investigated to explore the maximum extent of reaction and reported in the literature [28]. Solar-driven thermal reduction for ceria coupled with either $\mathrm{CO}_{2}$ or $\mathrm{H}_{2} \mathrm{O}$ splitting has been studied extensively by Welte $[41,56]$ and other researchers [5, 43]. However, limited literature on the thermodynamic assessment regarding methane reduction of ceria followed by splitting of waste gas (a mixture of $\mathrm{CO}_{2}$ and $\mathrm{H}_{2} \mathrm{O}$ ) is available [27]. Additionally, the need to identify 
the regimes for carbon formation is crucial to ensure the suitable operation regimes of the reaction system further.

Within the reduction reactor, carbon deposition, through Boudouard reaction (5) and methane dissociation mechanisms (6) is important. This carbon is subsequently transported into the oxidation reactor along with the reduced ceria. Within the oxidation reactor, even though the carbon does not directly inhibit any reaction, it forms its own set of reaction towards syngas production with $\mathrm{H}_{2} \mathrm{O}$ (water gas reaction) and $\mathrm{CO}_{2}$ (reverse boudouard reaction) as given by reactions (7) and (8), respectively. Therefore, the presence of carbon results in competitive reactions against the reduced metal oxide for the subsequent oxidation, which would cause the metal oxide to remain at a reduced state, while the solid carbon takes preference in oxidation. This would become more critical under a stoichiometric quantity of reactants, lowering the utilization of the metal oxide:

$$
\begin{aligned}
& 2 \mathrm{CO} \rightarrow \mathrm{C}(s)+\mathrm{CO}_{2} \\
& \mathrm{CH}_{4} \rightarrow \mathrm{C}(s)+2 \mathrm{H}_{2} \\
& \mathrm{C}(s)+\mathrm{H}_{2} \mathrm{O} \rightarrow \mathrm{CO}+\mathrm{H}_{2} \\
& \mathrm{C}(s)+\mathrm{CO}_{2} \rightarrow 2 \mathrm{CO}
\end{aligned}
$$

Besides carbon formation, the oxygen released from the reduced metal in the reduction reactor has the potential to react with the produced $\mathrm{CO}$ and $\mathrm{H}_{2}$ to form $\mathrm{CO}_{2}$ and water, respectively, at suitable thermodynamic conditions, as per Eqs. (9) and (10). This would considerably reduce the effectiveness of the entire system by lowering the calorific value of the syngas produced in the reduction reactor, thereby decreasing the system efficiency:

$\mathrm{CO}+0.5 \mathrm{O}_{2} \leftrightarrow \mathrm{CO}_{2}$
$\mathrm{H}_{2}+0.5 \mathrm{O}_{2} \leftrightarrow \mathrm{H}_{2} \mathrm{O}$

Based on the present chemical components, the water gas shift reaction (11) and the methane reformation reaction (12) can also occur. However, the thermodynamic and chemical conditions would render such reactions unfavourable from being primary contributors to system thermodynamics:

$\mathrm{CO}+\mathrm{H}_{2} \mathrm{O} \rightarrow \mathrm{CO}_{2}+\mathrm{H}_{2}$

$\mathrm{CH}_{4}+\mathrm{H}_{2} \mathrm{O} \rightarrow 3 \mathrm{H}_{2}+\mathrm{CO}$

Therefore, the aim of the present study was to perform thermodynamic and process simulation studies of the $\mathrm{CeO}_{2} /$ $\mathrm{Ce}_{2} \mathrm{O}_{3}$ redox pair chemical looping syngas production via methane reduction to obtain the ideal operating conditions, avoiding carbon deposition. The analysis has been performed by evaluating the thermodynamic equilibrium composition of the reaction system, the impact of the reactant feed molar ratios and temperature on the product compositions for the reduction and oxidation reactors, respectively. Furthermore, the redox cycle performance via system efficiency was also assessed.

\section{Thermodynamics method}

The thermodynamic simulation of methane reduction and water and $\mathrm{CO}_{2}$ splitting was performed in ASPEN Plus ${ }^{\circledR}$. Gibbs free energy minimization principle (GFEM) was used to perform the thermodynamic calculations. For a reaction system, where multiple simultaneous reactions take place, equilibrium calculations are often performed through the GFEM approach, details of which can be found in the literature $[10,20]$. For the entire set of reactors and components modelled, the gaseous species include $\mathrm{CH}_{4}$,
Fig. 2 Process simulation flowsheet of interconnected reduction and oxidation reactors

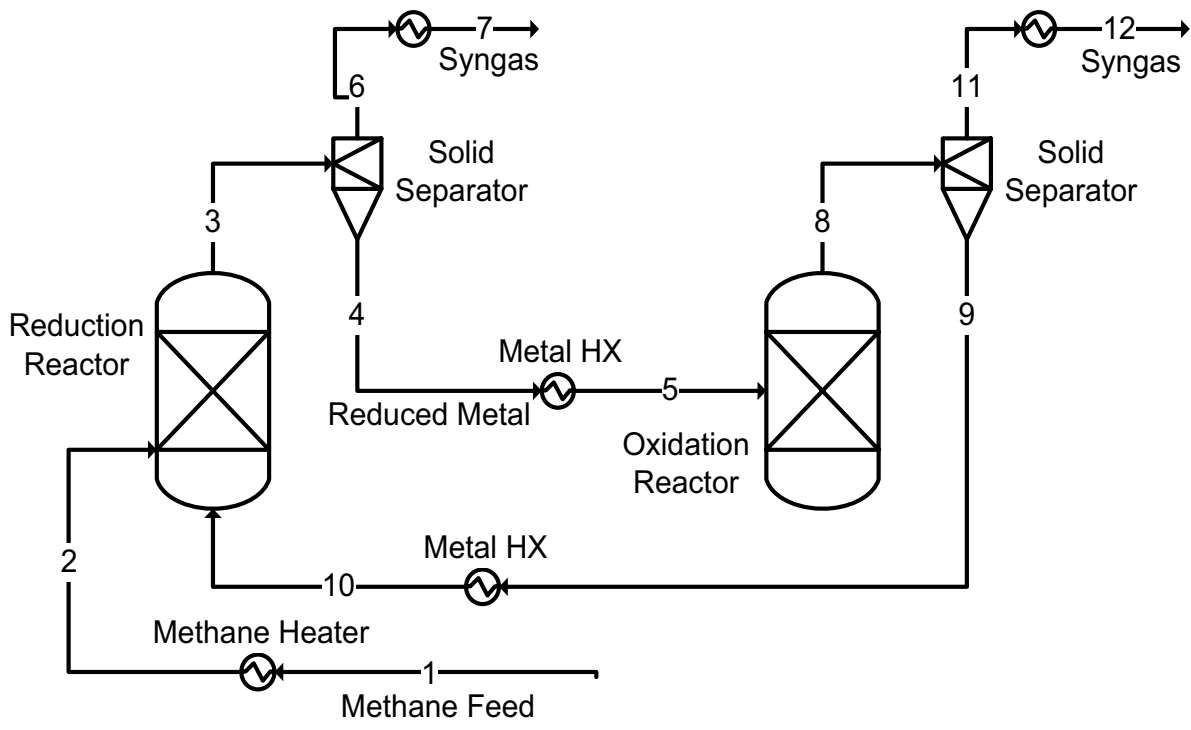


$\mathrm{CO}, \mathrm{CO}_{2}, \mathrm{H}_{2}$, and $\mathrm{H}_{2} \mathrm{O}$, while the solid species were $\mathrm{C}$, $\mathrm{Ce}_{2} \mathrm{O}_{3}$, and $\mathrm{CeO}_{2}$.

The process layout of the simulation system is shown in Fig. 2. The ASPEN Plus ${ }^{\circledR}$ RGIBBS reactor model was used to simulate both the reduction and oxidation reactors, using the Peng Robinson equation of state. Within the RGIBBS reactor, the equilibrium composition of all feasible combination of reactions within the thermodynamic domain was considered. The RGIBBS reactor calculates the most stable phase combination obtained through chemical reactions where the Gibbs free energy of the reaction system reaches its minimum at a fixed mass balance, constant pressure, and temperature. Besides the RGIBBS module, the other components simulated were cyclone units to separate solid and gas streams, and heat exchangers, in which steams are preheated to reach the temperatures of reaction and heat is removed from the reaction products.

For the reduction reactor, the temperature was varied in the range of $500-1000{ }^{\circ} \mathrm{C}$, at a constant pressure of $1 \mathrm{~atm}$. The $\mathrm{CH}_{4} / \mathrm{CeO}_{2}$ feed molar ratio was varied from 0.4 (substoichiometric value according to reaction (3)) to 4 . The solid product of the reduction reactor was fed to the oxidation reactor after cyclone separator. The oxidation reactor was modelled by a series of two RGIBBS reactors. The oxidation of $\mathrm{CO}_{2}$ and $\mathrm{H}_{2} \mathrm{O}$ over $\mathrm{Ce}_{2} \mathrm{O}_{3}$ is a highly exothermic reaction. Therefore, two rectors with an intercooler were modelled to simulate an ideal isothermal reactor. The first reactor was modelled as an adiabatic reactor, while the second reactor was an isothermal reactor, set at the temperature of the reaction. In the oxidation reactor, the $\mathrm{Ce}_{2} \mathrm{O}_{3}$ was reacted with a mixture of steam and carbon dioxide according to reactions (4a) and (4b). Similar to the reduction reactor, the oxidation reactor temperature was varied between 500 and $1000{ }^{\circ} \mathrm{C}$ at a constant pressure of $1 \mathrm{~atm}$. The feed flow of the mixture was varied between the range of 0.5 and $2 \mathrm{kmol} / \mathrm{h}$ (stoichiometric to excess flow). The study corresponding to the oxidation reactor was performed to obtain the quantitative $\mathrm{H}_{2}$ and $\mathrm{CO}$ produced at multiple regimes and hence identify the conditions of operations for different $\mathrm{H}_{2} / \mathrm{CO}$ ratio requirements for subsequent downstream processes. Additionally, determination of the minimum amount of gas flow and the corresponding composition to regenerate completely the reduced ceria was also aimed for within the regime of favourable reaction thermodynamics. However, it should be noted that, in the present study, all the simulation calculations performed were based on theoretical thermodynamic considerations, since no heat and mass diffusional limitations along with kinetic effects were considered conforming to the present thermodynamic analysis. This corresponds to the theoretical limits that must be considered during further experimental evaluations of the reaction systems.

\section{Results and discussion}

\section{Thermodynamic analysis}

\section{Reduction reactor}

The equilibrium composition of $\mathrm{H}_{2}, \mathrm{CO}, \mathrm{CO}_{2}, \mathrm{H}_{2} \mathrm{O}, \mathrm{O}_{2}$ and $\mathrm{CH}_{4}$ and $\mathrm{C}, \mathrm{CeO}_{2}$ and, $\mathrm{Ce}_{2} \mathrm{O}_{3}$ obtained from the reduction of methane over $\mathrm{CeO}_{2}$ in a temperature range of 500-1000 ${ }^{\circ} \mathrm{C}$ and $\mathrm{CH}_{4} / \mathrm{CeO}_{2}$ feed molar ratios from 0.4 to 4 are discussed in the following section.

Figure 3 shows the equilibrium production of $\mathrm{H}_{2}$ and $\mathrm{CO}$ within the reduction reactor (dry basis) as the molar fraction of the outlet product gas stream with respect to temperature and $\mathrm{CH}_{4} / \mathrm{CeO}_{2}$ feed molar ratio, together with the methane molar fraction at the outlet of the reactor. Oxygen, being always present in trace quantities in the product gas, has not been depicted separately. Additionally, the reduced $\mathrm{CeO}_{2}$ as a solid fraction is also plotted with respect to the mentioned conditions, as shown in Fig. 3d. Within the conditions investigated, the methane reduction reaction initiates over $600^{\circ} \mathrm{C}$. Lower methane to ceria ratios yielded lower products than higher feed ratios at same temperatures. At stoichiometric conditions, that is with $0.5 \mathrm{~mol} \mathrm{CH}_{4}$ per mole of $\mathrm{CeO}_{2}, 50 \%$ of $\mathrm{CeO}_{2}$ conversion occurs around $800{ }^{\circ} \mathrm{C}$, while the reaction yielded $99.9 \%$ conversion at temperatures over $900{ }^{\circ} \mathrm{C}$. This can be attributed to the intrinsic reactivity of solid $\mathrm{CeO}_{2}$ with respect to the gaseous fuel, methane, and availability of the metal oxide lattice oxygen into the gas phase for partial oxidation reactions. At lower temperatures $\left(500-600{ }^{\circ} \mathrm{C}\right)$ and for a lower $\mathrm{CH}_{4} / \mathrm{CeO}_{2}$ feed ratio (below 0.5), the availability of oxygen and temperature is limited to drive the reaction towards the production of syngas $\left(\mathrm{CO}+\mathrm{H}_{2}\right)$, resulting in the metal oxide to be poorly active for reaction (3). In any case, even with higher $\mathrm{CH}_{4} / \mathrm{CeO}_{2}$ feed ratio, the complete reaction occurs at temperatures over $700{ }^{\circ} \mathrm{C}$, providing a thermodynamic limit to the reduction temperature of pure $\mathrm{CeO}_{2}$ over methane.

Nevertheless, as can be visualized from Fig. 3, an operation with $0.7-0.8 \mathrm{~mol}^{\circ} \mathrm{CH}_{4}$ per mole of $\mathrm{CeO}_{2}$ at around $900-950{ }^{\circ} \mathrm{C}$ would provide the ideal operating conditions with respect to methane utilization, without the need to feed a high fraction of methane. A syngas stream of $31 \%$ $\mathrm{CO}$ and $63 \% \mathrm{H}_{2}$ can be obtained (balance $1 \% \mathrm{H}_{2} \mathrm{O}, 0.4 \%$ $\mathrm{CO}_{2}$ and $4.6 \% \mathrm{CH}_{4}$ ) at around $950{ }^{\circ} \mathrm{C}$ and $\mathrm{CH}_{4} / \mathrm{CeO}_{2}$ feed ratio of 0.7 to 0.8 . Indeed, for higher methane flows, the excess methane at the outlet of the reduction reactor would decrease the effectiveness of the chemical looping system.

Figure 4 highlights the molar fraction of unwanted chemical species in the outlet gas of the reduction reactor, produced simultaneously within the studied conditions,

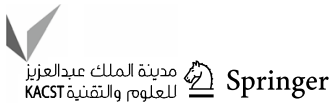




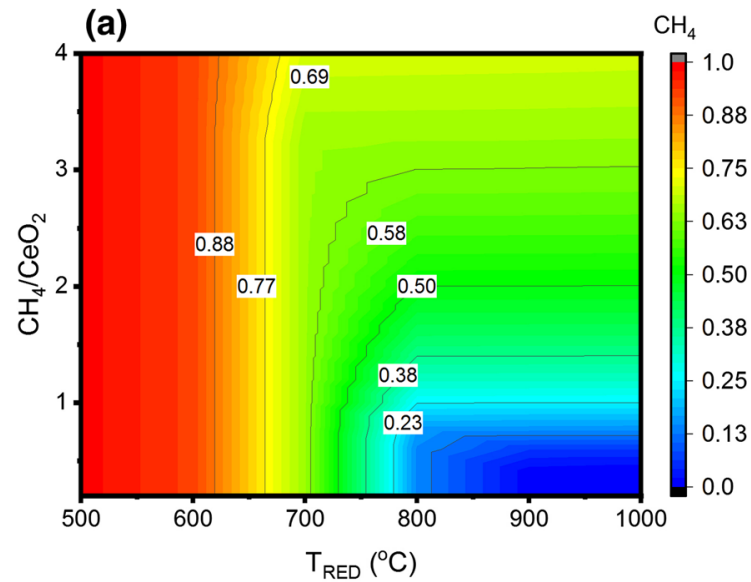

(c)

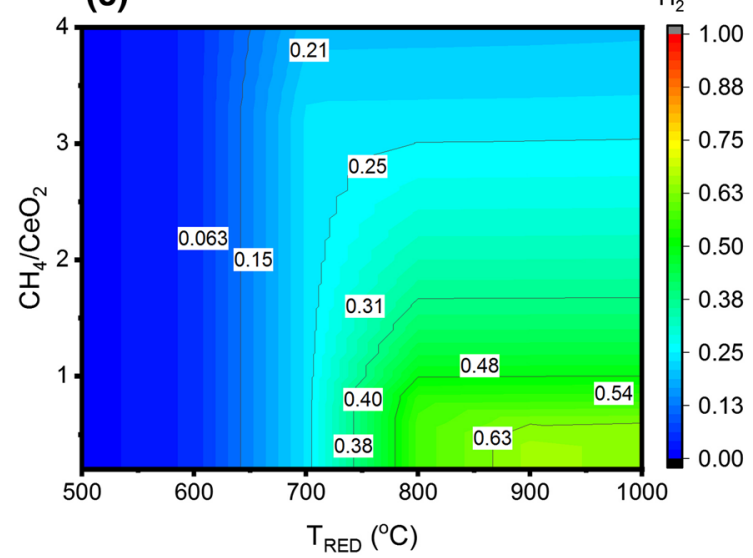

(b)

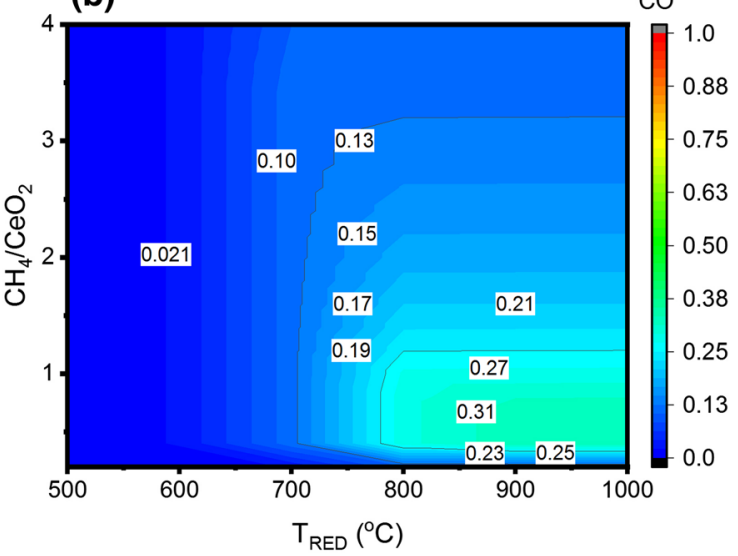

(d)

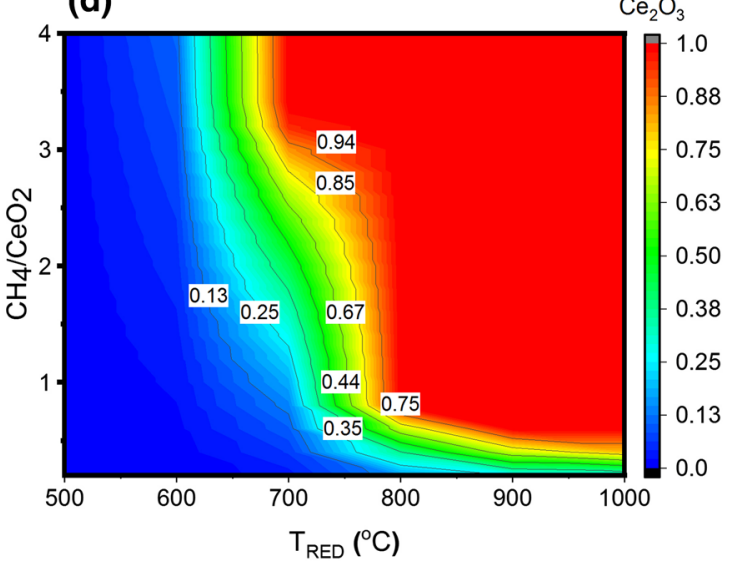

Fig. 3 Impact of the variation of the $\mathrm{CH}_{4} / \mathrm{CeO}_{2}$ ratio and temperature on the yield of the following chemical species as molar fractions of outlet streams within the reduction reactor: a unreacted methane; b $\mathrm{CO} ; \mathbf{c ~} \mathrm{H}_{2} ; \mathbf{d ~ C e} \mathrm{O}_{3} \mathrm{O}_{3}$ (solids)

(a)

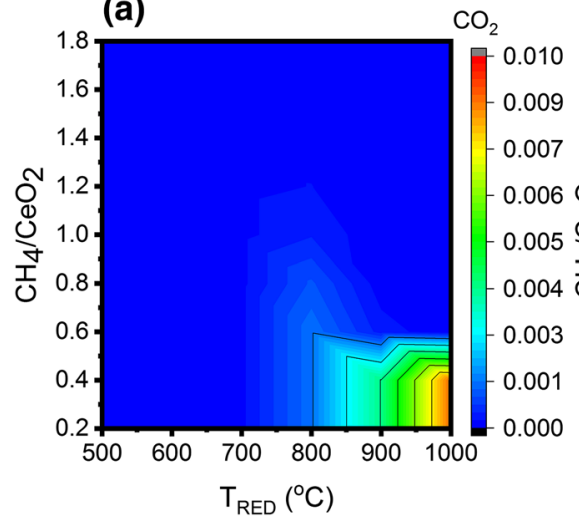

(b)

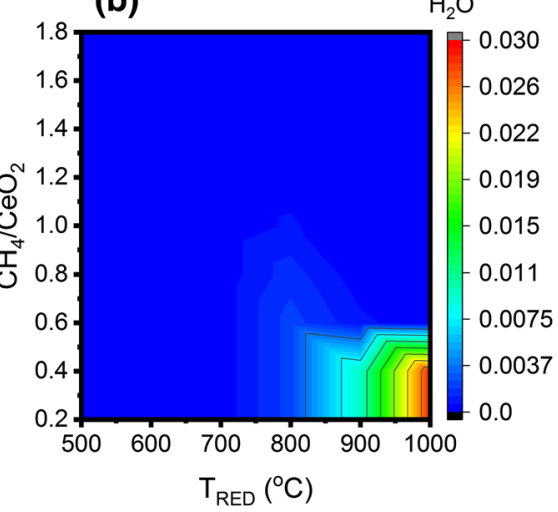

(c)

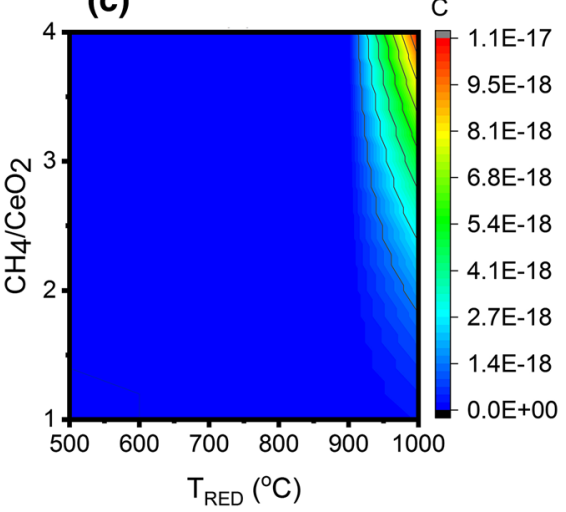

Fig. 4 Impact of the variation of the $\mathrm{CH}_{4} / \mathrm{CeO}_{2}$ ratio and temperature on the yield of the following unwanted chemical species as molar fraction of the outlet product streams within the reduction reactor: $\mathbf{a} \mathrm{CO}_{2} ; \mathbf{b ~} \mathrm{H}_{2} \mathrm{O}$; $\mathbf{c}$ elementary carbon (solids)

namely elementary carbon, $\mathrm{CO}_{2}$ and $\mathrm{H}_{2} \mathrm{O}$ resulting from the reactions (5-6) and (9-10). It can be observed that, at a higher temperature, and especially at a lower content of methane, there is a considerable increase in $\mathrm{CO}_{2}$ formation. A similar trend is observed for $\mathrm{H}_{2} \mathrm{O}$ formation, even though the yield of $\mathrm{H}_{2} \mathrm{O}$ is considerably higher than $\mathrm{CO}_{2}$, at corresponding temperature and pressure. Together, they make up about $4 \%$ of the product gas flow for near 
stoichiometric operations. The primary reason for the initiation of reactions (9) and (10) can be attributed to the lower availability of methane for reaction at higher temperatures. The oxygen released from the metal lattice reacts instead with the produced $\mathrm{CO}$ and $\mathrm{H}_{2}$ to oxidize them further into $\mathrm{CO}_{2}$ and $\mathrm{H}_{2} \mathrm{O}$.

As indicated in Fig. 4c, the carbon deposition initiates at methane to ceria feed ratios above 1.0 and a temperature above $900{ }^{\circ} \mathrm{C}$ and subsequently increases with higher molar flows of methane and temperature. This is because the thermodynamics for either the Boudouard and/or the methane decomposition reactions (Eq. 5, 6) are not favourable at other conditions. As discussed before, the production of carbon in the reduction reactor has considerable influence on the system efficiency due to competitive reactions with $\mathrm{Ce}_{2} \mathrm{O}_{3}$ in the oxidation reactor. Even though the fraction of carbon content is exceedingly low, this would restrict the working conditions with methane reduction to around $900{ }^{\circ} \mathrm{C}$, and the molar feed ratio, to less than or around 1.0.

The obtained thermodynamics results were further compared to the results of ceria reduction with methane as presented by Warren et al. [53]. Table 1 shows the thermodynamic results to the production of syngas and other gaseous components at the temperatures of 900 and $1000{ }^{\circ} \mathrm{C}$ and $0.25 \mathrm{~mol}$ of $\mathrm{CH}_{4} / \mathrm{mol} \mathrm{CeO}_{2}$. The current results show good agreement with those obtained in literature.

Combining all factors, as discussed above, it can be concluded that favourable operating zone of the reduction reactor has to be limited to around $900-950{ }^{\circ} \mathrm{C}$ with $0.7-0.8 \mathrm{~mol}$ of $\mathrm{CH}_{4}$ per mole of $\mathrm{CeO}_{2}$ to ensure complete reduction of $\mathrm{CeO}_{2}$, without the need of high methane content and avoiding unwanted reactions from taking place. This would also limit the sintering of ceria at this temperature which is supported by literature [51,59], where, in another reported study [47] the effect of sintering of ceria was not observed till $1623{ }^{\circ} \mathrm{C}(1900 \mathrm{~K})$. Moreover, in this operating range, the syngas obtained has the desired ratio of $\mathrm{H}_{2} / \mathrm{CO}$ equal to 2 , as shown in Fig. 5. Hence, in the subsequent analysis of system efficiency and sensitivity studies, the regime between 900 and $950{ }^{\circ} \mathrm{C}$ was used for the reduction reactor to evaluate the system performance.

Table 1 Comparison of thermodynamic results with results reported by Warren et al. [53] for the reduction of ceria with methane

\begin{tabular}{llllll}
\hline Temperature $\left({ }^{\circ} \mathrm{C}\right)$ & \multicolumn{5}{l}{ Mole fraction of exit gas } \\
\cline { 2 - 6 } & $\mathrm{H}_{2}$ & $\mathrm{CO}$ & $\mathrm{CH}_{4}$ & $\mathrm{H}_{2} \mathrm{O}$ & $\mathrm{CO}_{2}$ \\
\hline 900 & & & & & \\
{$[53]$} & 0.658 & 0.25 & 0.004 & 0.004 & 0 \\
Present study & 0.6523 & 0.327 & 0.006 & 0.009 & 0.001 \\
1000 & & & & & \\
{$[53]$} & 0.66 & 0.284 & 0 & 0 & 0 \\
Present study & 0.637 & 0.324 & 0 & 0.028 & 0.008 \\
\hline
\end{tabular}

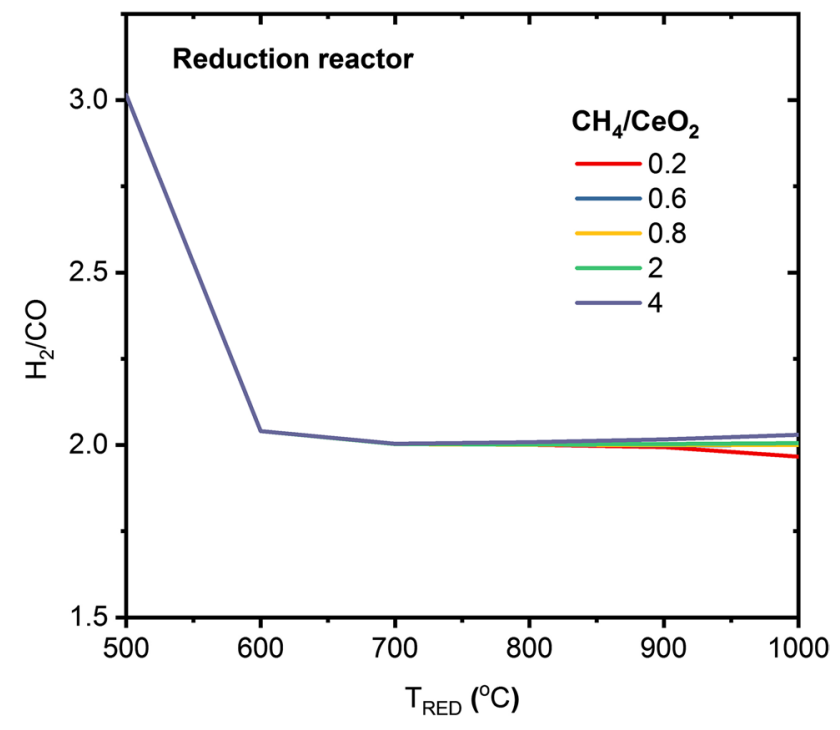

Fig. $5 \mathrm{H}_{2} / \mathrm{CO}$ ratio at the exit of the reduction reactor for different reduction temperatures for various $\mathrm{CH}_{4} / \mathrm{CeO}_{2}$

\section{Oxidation reactor}

The equilibrium amounts of $\mathrm{H}_{2}$ and $\mathrm{CO}$ obtained by splitting $\mathrm{CO}_{2}$ and $\mathrm{H}_{2} \mathrm{O}$ over reduced $\mathrm{Ce}_{2} \mathrm{O}_{3}$ within the oxidation reactor is presented in the following section. The parametric study was carried out within a temperature range of $500-1000{ }^{\circ} \mathrm{C}$, considering completely reduced Ceria $\left(\mathrm{Ce}_{2} \mathrm{O}_{3}\right)$ being fed into the oxidation reactor. A variation of $\mathrm{H}_{2} \mathrm{O} / \mathrm{CO}_{2}$ mixture composition (from $5 \%$ to $95 \% \mathrm{CO}_{2}$ ) and the molar flow rate of the mixture from 0.5 to $2 \mathrm{kmol} / \mathrm{h}$ was also performed. In all the cases the flow of $\mathrm{Ce}_{2} \mathrm{O}_{3}$ was kept constant at $0.5 \mathrm{kmol} / \mathrm{h}$, considered to be completely reduced from $1 \mathrm{kmol} / \mathrm{h}$ of $\mathrm{CeO}_{2}$ in the reduction reactor as per reaction (3).

For the base case study, an equimolar mixture between $\mathrm{H}_{2} \mathrm{O}$ and $\mathrm{CO}_{2}$ was fed into the oxidation reactor at varying feed rates and temperatures. Figure $6 \mathrm{a}$, b presents results from the oxidation reactor at the described conditions as the mole fraction of the products in the outlet gas stream from the reactor. It is observed that hydrogen production was obtained as a function of temperature and the feed molar flow to the reactor. Therefore, the region of maximum hydrogen production can be identified, varying between 600 and $700{ }^{\circ} \mathrm{C}$, depending on the molar feed flow rate. With higher feed flow rate, the peak of hydrogen shifts towards a lower temperature. More specifically, for a waste gas flow rate of $1 \mathrm{kmol} / \mathrm{h}$, for an equimolar mixture between $\mathrm{CO}_{2}$ and $\mathrm{H}_{2} \mathrm{O}$, with each $0.5 \mathrm{kmol} / \mathrm{h}$, the peak hydrogen production occurs around $650{ }^{\circ} \mathrm{C}$, which shifts to $600{ }^{\circ} \mathrm{C}$ with an increase of the molar feed rate of $2 \mathrm{kmol} / \mathrm{h}$.

On the other hand, the $\mathrm{CO}$ yield increases at a higher rate till around $650{ }^{\circ} \mathrm{C}$, after which the rate of increase of $\mathrm{CO}$ 

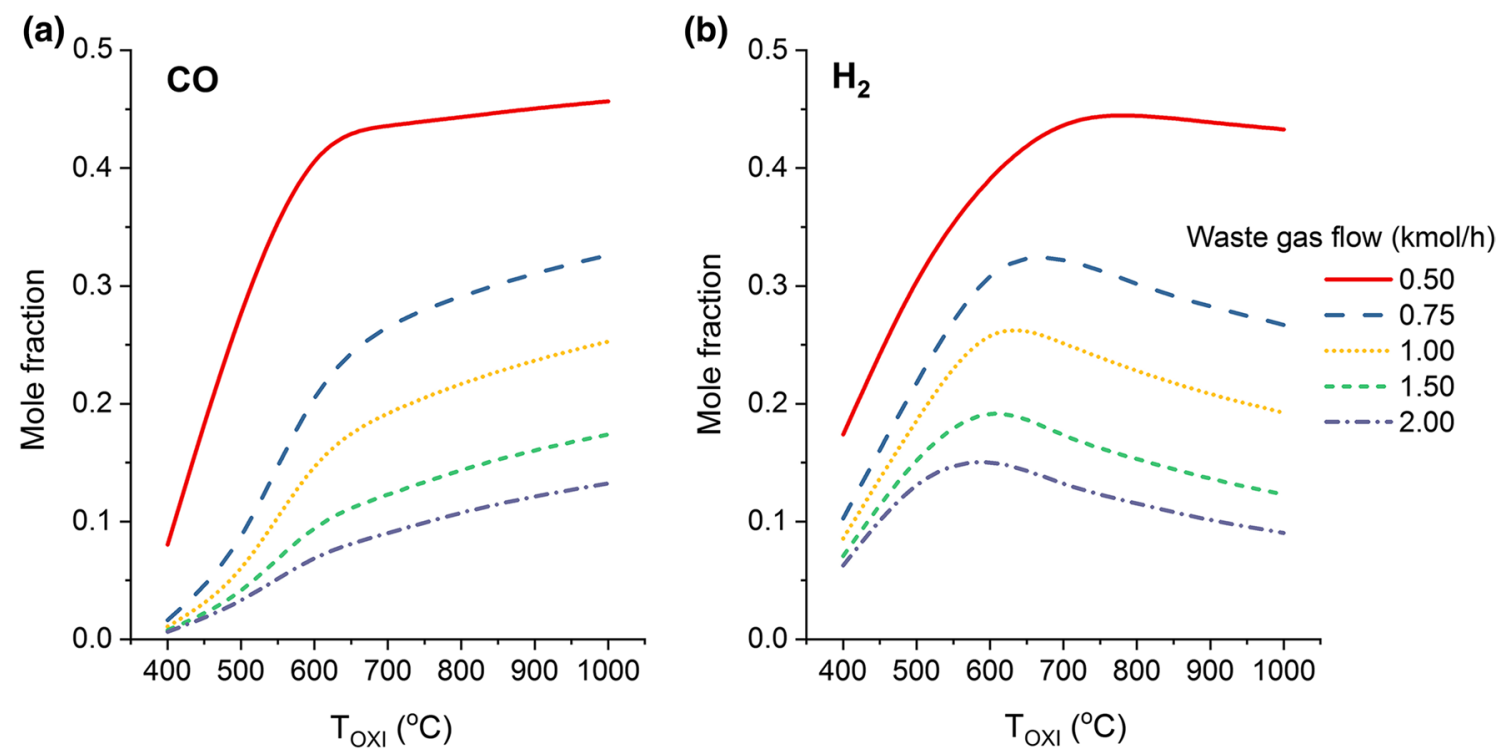

Fig. 6 Impact of the variation of the waste gas (equimolar mixture of $\mathrm{CO}_{2}$ and $\mathrm{H}_{2} \mathrm{O}$ ) flow rate and temperature on the yield of the $\mathbf{a} \mathrm{CO}$ and $\mathbf{b} \mathrm{H}_{2}$ as the molar fraction of the product gas of the oxidation reactor

yield drops considerably. The higher the flow of the waste gas, the lower the difference in the rate of yield increase between the two temperature ranges (below and above $\left.650^{\circ} \mathrm{C}\right)$. For molar flows higher than stoichiometry $(0.5$ $\mathrm{kmol} / \mathrm{h}$ ), the yield becomes stable at about $0.28 \mathrm{kmol} / \mathrm{h}$ with a further rise in temperature, irrespective of the increase in molar feed flow.

The yield variations based on the thermodynamic conditions play a critical role in varying $\mathrm{H}_{2} / \mathrm{CO}$ ratio obtained at the outlet of the oxidation reactor, which, therefore, can be controlled to obtain the $\mathrm{H}_{2} / \mathrm{CO}$ ratios required for specific processes. Combining the yields of the two gases, for the stoichiometric flow of waste gas $(1 \mathrm{kmol} / \mathrm{h}$ and equimolar mixture), a syngas stream of $45 \% \mathrm{H}_{2}$ and above $40 \% \mathrm{CO}$ could be obtained. The remaining fraction of the gas is composed of un-reacted species. However, sending abovestoichiometric flows, even though it would result in complete oxidation of $\mathrm{Ce}_{2} \mathrm{O}_{3}$ and providing maximum yield, would result in syngas fraction to drop considerably. This would decrease the effectiveness of the process by requiring additional downstream processes to separate $\mathrm{CO}_{2}$ and water for obtaining pure syngas.

The $\mathrm{H}_{2}$ and $\mathrm{CO}$ results can be combined to obtain the $\mathrm{H}_{2} /$ $\mathrm{CO}$ ratios at the outlet of the oxidation reactor with varying molar feed flows of the equimolar mixture of $\mathrm{H}_{2} \mathrm{O}$ and $\mathrm{CO}_{2}$ as presented in Fig. 7a. At lower temperatures, the formation of $\mathrm{H}_{2}$ is thermodynamically favourable over that of $\mathrm{CO}$. Additionally, with an increase in molar feed rate, the preferential splitting of water over carbon dioxide increases the $\mathrm{H}_{2} / \mathrm{CO}$ ratio further at lower temperatures. The $\mathrm{H}_{2} / \mathrm{CO}$ ratio decreases considerably with an increase of temperature to around a constant 0.6 at $1000{ }^{\circ} \mathrm{C}$, irrespective of the waste gas feed flow, as $\mathrm{H}_{2}$ formation peaks around $600-650{ }^{\circ} \mathrm{C}$, while there is no specific peak for $\mathrm{CO}$ formation that constantly increases with the temperature. Also, interestingly, at a lower flow of $0.5 \mathrm{kmol} / \mathrm{h}$ of the waste gas, when neither of the chemical species can completely oxidize the reduced metal, the $\mathrm{H}_{2} / \mathrm{CO}$ ratio remains constant at around 0.6, irrespective of the temperature variation. This can be concluded from the fact that the $\mathrm{H}_{2} \mathrm{O}$ and $\mathrm{CO}_{2}$ splitting can then occur simultaneously since the individual gases are lower than the stoichiometric quantity necessary to oxidize the reduced metal by themselves as per reaction (4). However, it needs to be kept in mind that the complete oxidation of the $\mathrm{Ce}_{2} \mathrm{O}_{3}$ to $\mathrm{CeO}_{2}$ was ensured within the defined conditions, and the produced $\mathrm{CeO}_{2}$ was recirculated back to the reduction reactor.

The variation of the ratios $\mathrm{H}_{2} / \mathrm{CO}$ from the oxidation reactor, based on varying compositions of $\mathrm{H}_{2} \mathrm{O}$ and $\mathrm{CO}_{2}$ at a constant waste gas feed flow of $1 \mathrm{kmol} / \mathrm{h}$ of the mixture, is presented in Fig. 7b. The formation of $\mathrm{H}_{2}$ is 18 times more than that of $\mathrm{CO}$ for a waste gas containing $80 \%$ of water vap+ and $20 \%$ of $\mathrm{CO}_{2}$ at a temperature of $500{ }^{\circ} \mathrm{C}$. However, at the same temperature, for a gas containing $80 \% \mathrm{CO}_{2}$, the $\mathrm{H}_{2} / \mathrm{CO}$ ratio is about the same ratio as $\mathrm{H}_{2} \mathrm{O}$ / $\mathrm{CO}_{2}$. Indeed, as can be followed from the previous discussions, with the formation of $\mathrm{H}_{2}$ peaking at around $600{ }^{\circ} \mathrm{C}$, with the corresponding increase in the $\mathrm{CO}$ yield, the ratio of $\mathrm{H}_{2} / \mathrm{CO}$ decreases to about 2.5 even with $80 \% \mathrm{H}_{2} \mathrm{O}$ at the feed stream. This would result in the outlet gas to contain a significant fraction of unreacted $\mathrm{H}_{2} \mathrm{O}$, while all the $\mathrm{CO}_{2}$ would have been converted to $\mathrm{CO}$. At higher fractions of 


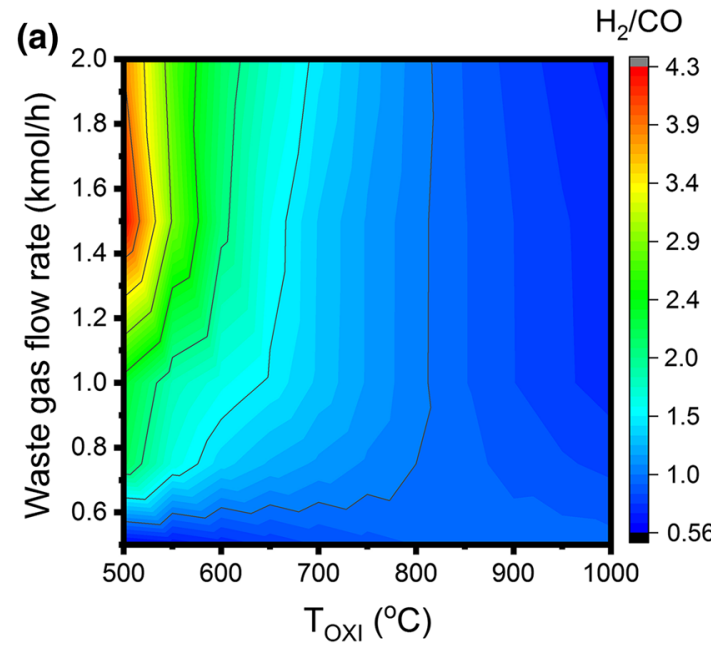

Fig. 7 Impact of the variation of the waste gas flow parameters and temperature on the $\mathrm{H}_{2} / \mathrm{CO}$ yield ratio in the oxidation reactor: a variation of flow of waste gas with an equimolar mixture of $\mathrm{CO}_{2}$ and $\mathrm{H}_{2} \mathrm{O}$;

$\mathrm{CO}_{2}$, higher temperatures would yield better result from the conversion perspective of the waste gas feed. It needs to be mentioned that higher flow rates were also studied for variation of composition with similar trends and hence not shown separately in the paper. By such consideration, therefore, the need for determining the operating temperature of the oxidation reactor, depending on the composition of the waste gas, would play a crucial role in determining the most effective conversion, besides ensuring complete oxidation of the reduced metal. Also, the importance of the requirement of the $\mathrm{H}_{2} / \mathrm{CO}$ ratio for subsequent downstream processes is to be given importance. Nonetheless, it can be concluded that for waste gases, with large fractions of water content, it is preferable to maintain the oxidation reactor at a temperature (b)

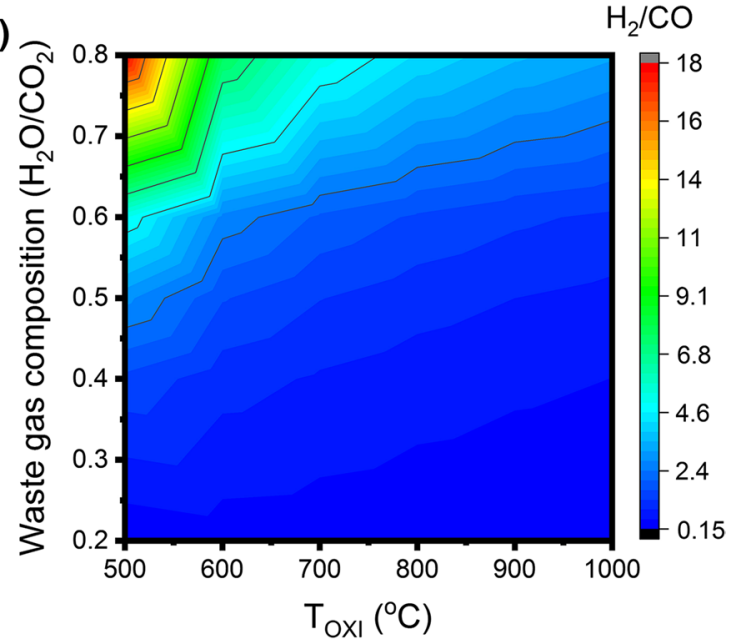

b variation of the composition of the waste gas at a constant waste gas feed rate of $1 \mathrm{kmol} / \mathrm{h}$

about $600-700{ }^{\circ} \mathrm{C}$ to ensure maximum reactivity of $\mathrm{H}_{2} \mathrm{O}$. However, for higher $\mathrm{CO}_{2}$ content, typically occurring for exhaust of power plants, the temperature of the oxidation reactor can be set at higher temperatures of around or above $900{ }^{\circ} \mathrm{C}$, thereby ensuring high conversion of $\mathrm{CO}_{2}$, and also presenting the possibility to operate the redox cycle at isothermal conditions.

\section{Heat balance}

The heat necessary for the reactions to occur in the reduction reactor and the heat that must be removed from the oxidation reactor to ensure the isothermal operation is plotted in Fig. 8a, b, respectively. The methane reduction reaction is
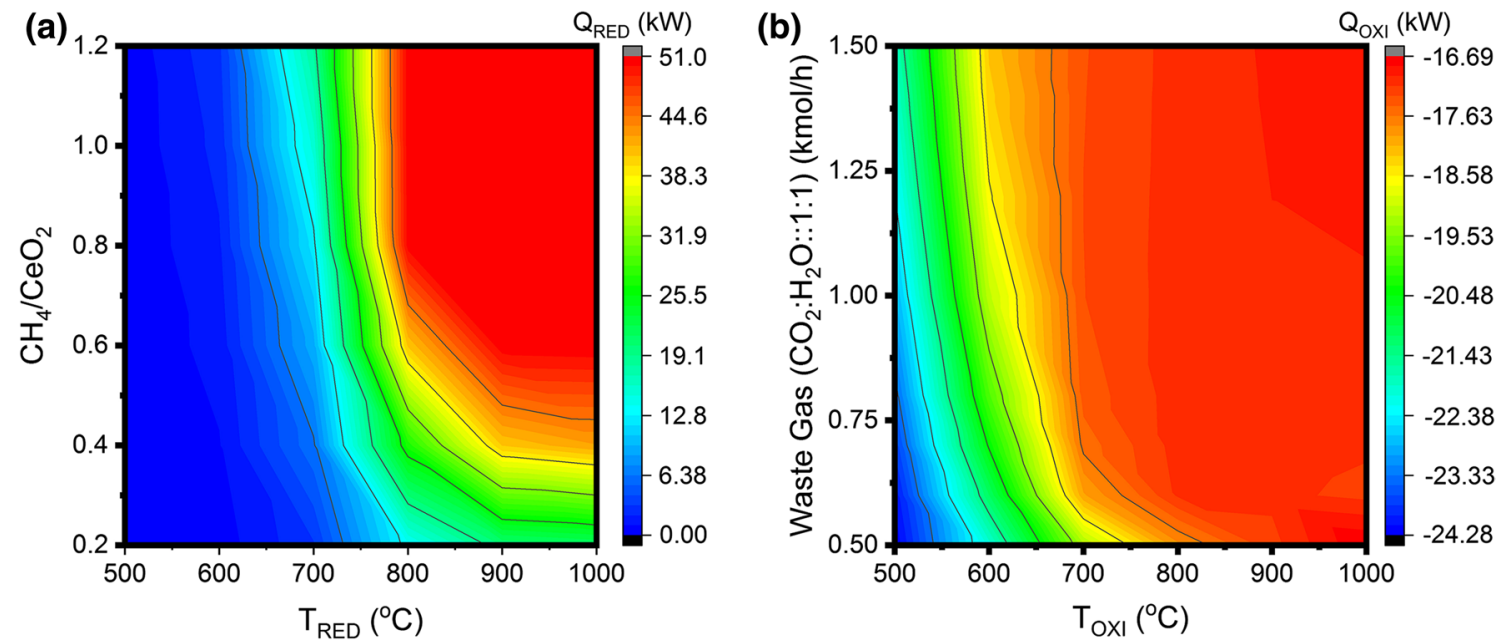

Fig. 8 Heat need/release from the reduction and oxidation reactions as per: a with a variation of $\mathrm{CH}_{4} / \mathrm{CeO}_{2}$ feed ratio and temperature in the reduction reactor; $\mathbf{b}$ with a variation of the waste gas flow at an equimolar mixture composition and temperature in the oxidation reactor 
endothermic over the entire thermodynamic conditions studied in the paper. Interesting, however, is to note the similarity of the heat demand curve with the reaction extent plot, as in Fig. 8. The lower heat rates at lower temperatures and molar feed ratio can be attributed to the lower reactivity between ceria and methane. However, with complete reactivity, the heat requirement stabilizes to $50 \mathrm{~kW}$ per mole of $\mathrm{CeO}_{2}$ reduced. Indeed, for complete conversion of methane, with a molar feed rate ratio of over $0.7-0.8$, and above $900{ }^{\circ} \mathrm{C}$, the heat required for the reaction to occur stabilizes.

On the other hand, the oxidation reaction is exothermic over the entire thermodynamic conditions considered in the paper. As follows from thermodynamic laws, an exothermic reaction is favoured at lower temperatures. This is indeed represented in Fig. 8b, where, at lower temperatures, the heat released from the reaction is much more pronounced, than the heat released at higher temperatures. Additionally, at lower temperatures, the heat released is primarily from the splitting of water, which is much more exothermic than the corresponding $\mathrm{CO}_{2}$ splitting reaction, which gains predominance at higher temperatures. However, the overall reaction continues to be exothermic. Indeed, the drop of exothermicity at higher temperatures impacts on the overall system efficiency and thermodynamics and has been subsequently discussed in the following sections.

As discussed, the advantage of ceria reduction by methane is the lowering of the reduction temperature. Therefore, as can be deduced from the present analysis, an isothermal system with complete reduction and oxidation of ceria in the respective reactors can be obtained via the present layout. This, however, would limit the isothermal operation zone to between 850 and $950^{\circ} \mathrm{C}$, since this would ensure the complete reduction and corresponding oxidation of $\mathrm{CeO}_{2}$ with the selected flow of methane as discussed earlier. In fact, it is interesting to note that even though the oxidation reactor is exothermic, the exothermicity is lower than the endothermicity of the reduction reactor within the defined range of isothermal operations. Hence, external heat would be required for driving the system. This can be achieved either by utilizing concentrated solar power [57] or by burning additional fuel.

\section{Efficiency assessment}

\section{Definition}

To evaluate the system performance and identify the scope of improvement, the efficiency of the system plays a significant role. As the case, two parallel streams of syngas are produced, of which, however, the syngas from the oxidation reactor is the main aim of such thermo-chemical cycles, as the goal of the system is to produce syngas from waste streams of $\mathrm{CO}_{2}$ and $\mathrm{H}_{2} \mathrm{O}$. In the reduction reactor, methane is converted to syngas to drive the redox cycle with the methane content in the syngas varying significantly depending on the operating conditions of the reactor (i.e., temperature and $\mathrm{CH}_{4} / \mathrm{CeO}_{2}$ fraction), as discussed previously in the paper. Even with high fractions of unreacted $\mathrm{CH}_{4}$, this syngas can be utilized for multiple purposes as well. Besides being further upgraded to syngas by chemical conversions via steam reforming reactions, it can be utilized directly for combustion. However, efficiencies of such conversions are directly dependant on the downstream conversion process required and hence was left out of scope within the present definitions. In the case that the methane is fully converted, and the reduction syngas composition matches with the one of the syngas obtained in the oxidation reactor, the two syngas flows can be mixed for subsequent use in the same process.

Therefore, considering the diverse opportunities, two efficiencies were defined for the proposed system considering the performance of both the reactors, the preheating requirements of the solids and gas reactants in both the reactors, as well as the heat recuperated from solid. The first efficiency takes into account the syngas produced in both the reactors, while the second efficiency is defined considering only the syngas from the splitting of $\mathrm{CO}_{2}$ and $\mathrm{H}_{2} \mathrm{O}$ in the oxidation reactor.

Based on the above-described conditions, Eq. (12) depicts the system efficiency for the two-step chemical looping syngas production via methane reduction and subsequent $\mathrm{CO}_{2}$ and $\mathrm{H}_{2} \mathrm{O}$ splitting considering syngas produced in both the reactors, while Eq. (13) depicts the system efficiency considering only the syngas produced in the oxidation reactor:

$$
\begin{aligned}
& \eta_{1}=\frac{\left(\dot{m}_{\mathrm{H}_{2}} \mathrm{LHV}_{\mathrm{H}_{2}}+\dot{m}_{\mathrm{CO}} \mathrm{LHV}_{\mathrm{CO}}\right)_{\mathrm{RED}}+\left(\dot{m}_{\mathrm{H}_{2}} \mathrm{LHV}_{\mathrm{H}_{2}}+\dot{m}_{\mathrm{CO}} \mathrm{LHV}_{\mathrm{CO}}\right)_{\mathrm{OXI}}}{\left(\dot{m}_{\mathrm{CH}_{4}} \mathrm{LHV}_{\mathrm{CH}_{4}}+\left(\dot{Q}_{\mathrm{RED}}-\dot{Q}_{\mathrm{OXI}}\right)+\dot{Q}_{\text {need, net }}\right)+\left(\dot{Q}_{\mathrm{sphtr}}-\dot{Q}_{\mathrm{sld}}\right)} \\
& \eta_{2}=\frac{\left(\dot{m}_{\mathrm{H}_{2}} \mathrm{LHV}_{\mathrm{H}_{2}}+\dot{m}_{\mathrm{CO}} \mathrm{LHV}\right.}{\left.\left(\dot{\mathrm{m}}_{\mathrm{CH}_{4}}\right)_{\mathrm{OXI}} \mathrm{LHV}_{\mathrm{CH}_{4}}+\left(\dot{Q}_{\mathrm{RED}}-\dot{Q}_{\mathrm{OXI}}\right)+\dot{Q}_{\text {need, net }}\right)+\left(\dot{Q}_{\mathrm{sphtr}}-\dot{Q}_{\mathrm{sld}}\right)}
\end{aligned}
$$

where $Q_{\mathrm{RED}}$ is the heat requirement at the reduction reactor, $Q_{\mathrm{OXI}}$ is the heat released from the oxidation reactor, $Q_{\text {need,net }}$ $=\left(Q_{\text {need,CH4 }}+Q_{\text {need,waste gas }}\right)-\left(Q_{\text {syngas,OXI }}+Q_{\text {syngas,RED }}\right)$ is the net heat needed for the system operations, including the heat needed for methane and waste gas heat-up and the heat recovered from the syngas product streams, that are directly used to pre-heat the inlet gases, and hence included in the defined manner. $\left(Q_{\text {sphtr }}-Q_{\text {sld }}^{*}\right)$ represents the net heat required to preheat the solids in case of the operation of the two reactors at different temperatures, with the reduction reactor usually at a higher temperature due to thermodynamic considerations. $Q_{\text {sld }}$ represents the heat recovered from the solids from the reduction reactor before it enters oxidation, while $Q_{\text {sphtr }}$ is the heat delivered to the solids for preheating. Heat losses from system components were neglected in the efficiency assessment. 


\section{Efficiency evaluation}

To illustrate the benefits of the proposed cycle as per the definition of efficiency, the results of the effect of the operating parameters on the efficiency of the system are presented in the following section. The impact of the variation of the feed flow rate of the oxidation reactor, as well as the variation of the gas composition on the overall system efficiency, for constant methane to ceria feed ratio of 0.8 to the reduction reactor is shown in Fig. 9. The impact on the combined efficiency definition, considering both the reactors, has been discussed since a constant $\mathrm{CH}_{4} / \mathrm{CeO}_{2}$ ratio of 0.8 would yield a fixed output from the reduction reactor above $900{ }^{\circ} \mathrm{C}$. The optimal temperature of operation of the reduction reactor being identified as $900{ }^{\circ} \mathrm{C}$, the efficiency study has been carried out at temperatures of $900{ }^{\circ} \mathrm{C}$ and $950{ }^{\circ} \mathrm{C}$. It is seen that neither the variation of the flow of the waste gas nor the composition of the gas has a significant impact on the net system efficiency. A slight decrease in the efficiency is, however, noticed for an increased water content for the waste gas flow. Acknowledging the fact that the minimum flow, that is $0.5 \mathrm{kmol} / \mathrm{h}$ of waste gas, corresponds to the stoichiometric conditions, and that the present thermodynamic conditions are feasible for the splitting reactions, (4a) and (4b), the results indicate the complete oxidation of the reduced metal. Indeed, with an increase in the flow of waste gas, stoichiometric fraction of the $\mathrm{CO}_{2}$ and $\mathrm{H}_{2} \mathrm{O}$ takes part in the reaction, with the excess gases remaining unreacted.

The impact of the variation of the methane to ceria feed flow in the reduction reactor on the system efficiency, considering syngas from both the reactors, is shown in Fig. 10, together with the corresponding total $\mathrm{CO}$ and $\mathrm{H}_{2}$ yield as obtained from both the reactors. The feed flow in the oxidation reactor was kept constant at $1 \mathrm{kmol} / \mathrm{h}$, and an equimolar flow of $\mathrm{CO}_{2}$ and $\mathrm{H}_{2} \mathrm{O}$ was considered, with an isothermal redox cycle operation between 800 and $950{ }^{\circ} \mathrm{C}$. At $800{ }^{\circ} \mathrm{C}$ and with $\mathrm{CH}_{4} / \mathrm{CeO}_{2}$ flow ratio of up to 0.8 , the metal oxide remains largely unreacted, leading to system efficiencies of about $60 \%$, always lower than that of the system working at higher temperatures of $900{ }^{\circ} \mathrm{C}$ and $950{ }^{\circ} \mathrm{C}$. At temperatures over $850^{\circ} \mathrm{C}$, the methane conversion becomes $99 \%$, even at lower than stoichiometric flow rates. However, with lower than stoichiometric flow rates of methane to the reduction reactor, even though methane conversion is maximum, a part of the ceria remains unreacted. By definition of efficiency, this leads to a high system efficiency of around $90 \%$, even though the total yield of $\mathrm{CO}$ and $\mathrm{H}_{2}$ is considerably less than the maximum potential. At methane to ceria flow ratio of 0.5 and below, the yield corresponds to only around $50 \%$ of the maximum potential yield of the redox system, which starts occurring at $\mathrm{CH}_{4} / \mathrm{CeO}_{2}$ flow ratios of 0.7 at temperatures over $850^{\circ} \mathrm{C}$ and 0.8 for a temperature of $800{ }^{\circ} \mathrm{C}$. Indeed, once the yield of the system becomes comparable irrespective of temperature at $\mathrm{CH}_{4} / \mathrm{CeO}_{2}$ flow ratio over 0.8 , the system efficiency starts becoming comparable, irrespective of the working temperature of the system.

Based on the defined efficiency $\eta_{1}$ the excess methane plays no significant role in increasing the $\mathrm{H}_{2}$ and $\mathrm{CO}$ yield of the system; however, it decreases the system efficiency. Following the discussion, to ensure high system efficiency together with maximum possible system yield, the system should operate with a $\mathrm{CH}_{4} / \mathrm{CeO}_{2}$ molar feed ratio between 0.7 and 0.8 at a temperature of $900{ }^{\circ} \mathrm{C}$ or higher. In these conditions the efficiency is around 60 to $70 \%$, yielding $1.2 \mathrm{kmol} / \mathrm{h}$ of $\mathrm{H}_{2}$ and $0.8 \mathrm{kmol} / \mathrm{h}$ of $\mathrm{CO}$ from a stream of 1 $\mathrm{kmol} / \mathrm{h}\left(\mathrm{CO}_{2} / \mathrm{H}_{2} \mathrm{O}\right.$ ratio equal to 1$)$.

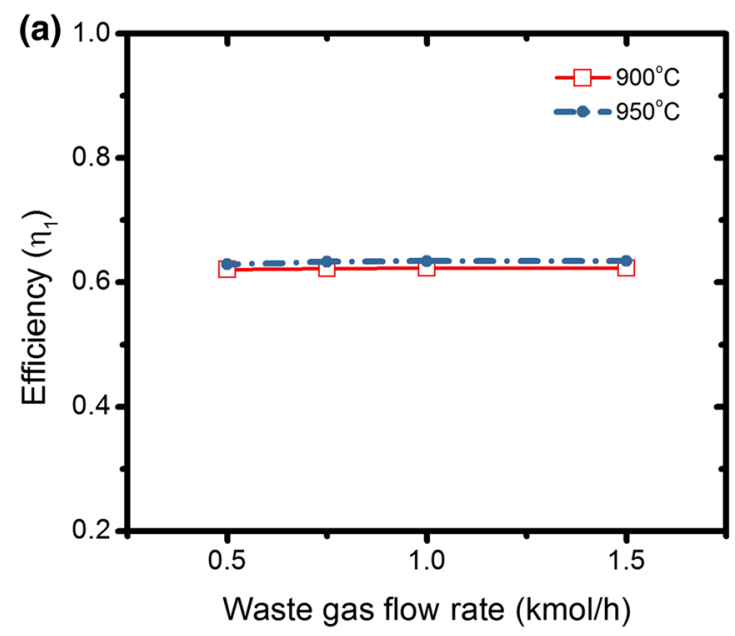

Fig. 9 Variation of system efficiency considering syngas from both the reactors $\left(h_{1}\right)$ based on the parametric variations within the oxidation reactor, at a constant $\mathrm{CH}_{4} / \mathrm{CeO}_{2}$ flow ratio of 0.8 in the reduction

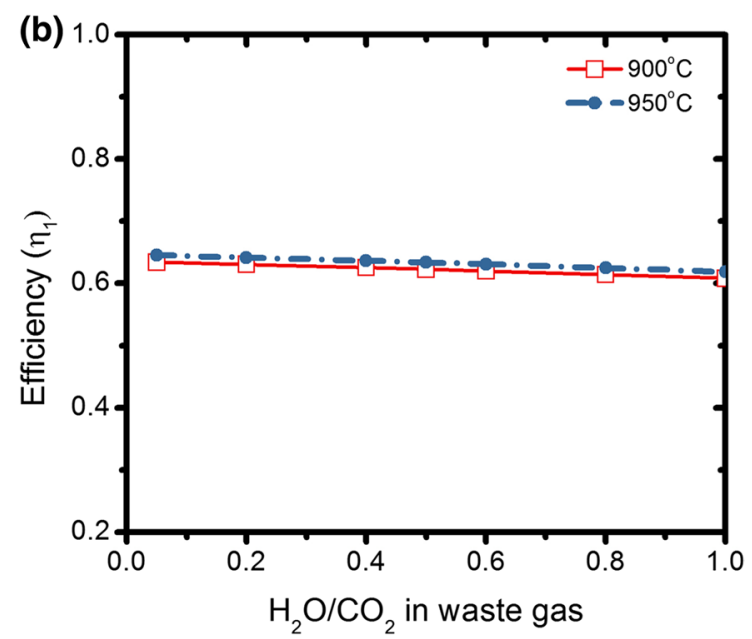

reactor based on a variation of waste gas flow rate at a constant equimolar mixture of $\mathrm{CO}_{2}$ and $\mathrm{H}_{2} \mathrm{O}$ and temperature; $\mathbf{b}$ variation of waste gas composition and temperature

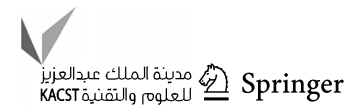



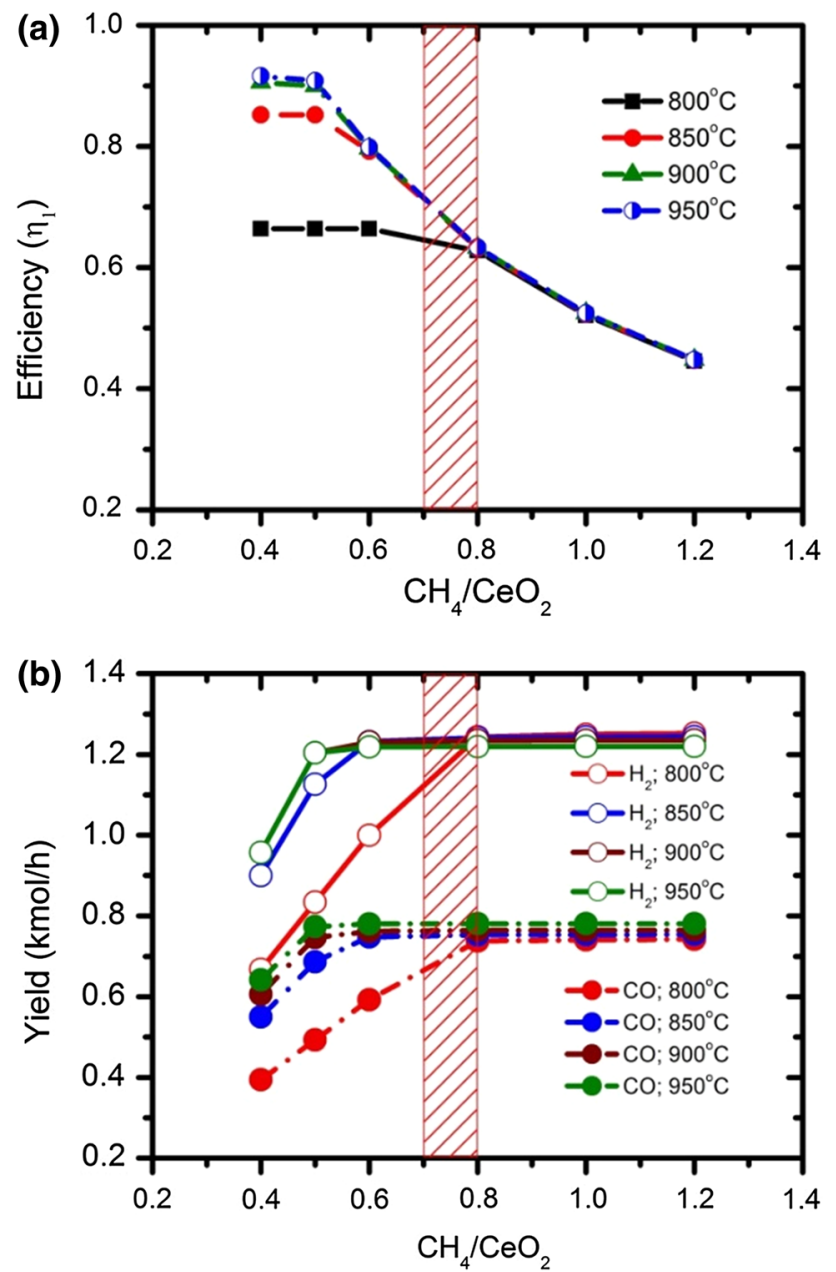

Fig. 10 Impact of the $\mathrm{CH}_{4} / \mathrm{CeO}_{2}$ molar feed ratio and temperature, based on an isothermal system operation and a constant flow of 2 $\mathrm{kmol} / \mathrm{h}$ of waste gas at equimolar composition within the oxidation reactor on a the system efficiency, $\eta_{1}$, b net $\mathrm{H}_{2}$ and $\mathrm{CO}$ yield from the redox cycle, considering both the oxidation and reduction reactors

Corresponding to the definition of the system efficiency with only the yield from the splitting reaction, an overall system efficiency of $16 \%$, corresponding to the maximum system yield is obtained, as can be visualized from Fig. 11. This result, indeed, is comparable to solar thermochemical cycles, showing similar efficiency trends where only syngas from splitting reaction is prevalent. The trend of both the efficiencies is, however, similar, further justifying the need to operate within the specific region as already discussed in the previous sections for maximum system effectiveness and resource utilization.

Pinch analysis The pinch analysis has been also performed to evaluate the thermal integration within the thermochemical cycle for an isothermal operation at $950{ }^{\circ} \mathrm{C}$. Results are shown in Fig. 12.

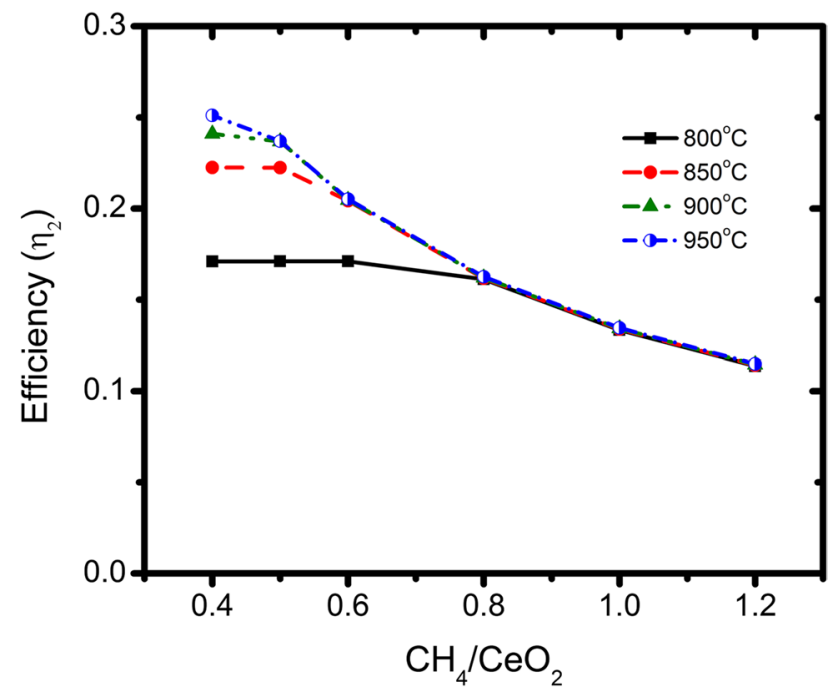

Fig. 11 Impact of the $\mathrm{CH}_{4} / \mathrm{CeO}_{2}$ molar feed ratio and temperature, on the system efficiency considering only the yield from $\mathrm{CO}_{2}$ and $\mathrm{H}_{2} \mathrm{O}$ splitting $\left(\eta_{2}\right)$, based on isothermal system operation and a constant flow of $1 \mathrm{kmol} / \mathrm{h}$ of waste gas at equimolar composition within the oxidation reactor

As can be seen, the amount of high-temperature heat needed is significant due to the highly endothermic reduction reaction. Such heat, however, can be provided either through concentrated solar energy — even if this option could not allow the continuous operation of the system-or by burning a fuel, for example, additional methane or renewable fuels, thereby enabling the system to run continuously. Even combined solutions can be proposed, by providing heat from burning fuels only to integrate the solar heat flux when it is not sufficient. The analysis of these solutions has not been included in the paper, as it is outside of the scope.

Indeed, as can be seen, due to the considerable amount of heat content from the exit product gas streams from both the reactors, a considerable amount of heat is available at lower temperatures, increasing the system performance as per the defined efficiencies. Integration with larger systems, therefore, would yield benefits through the availability of significant amounts of low-temperature waste heat.

\section{Conclusions}

In the present paper, the performance of the $\mathrm{CeO}_{2} / \mathrm{Ce}_{2} \mathrm{O}_{3}$ redox pair was evaluated for chemical looping syngas production through methane reduction and carbon dioxide and water splitting using thermodynamic analysis. Process simulation was performed to identify the limiting, as well as the most favourable working conditions with corresponding efficiency evaluation. In the fuel reactor, syngas production was studied via reduction of the metal oxide by methane. For 
Fig. 12 Pinch Analysis of the methane-driven chemical looping cycle at an isothermal temperature of $950{ }^{\circ} \mathrm{C}$

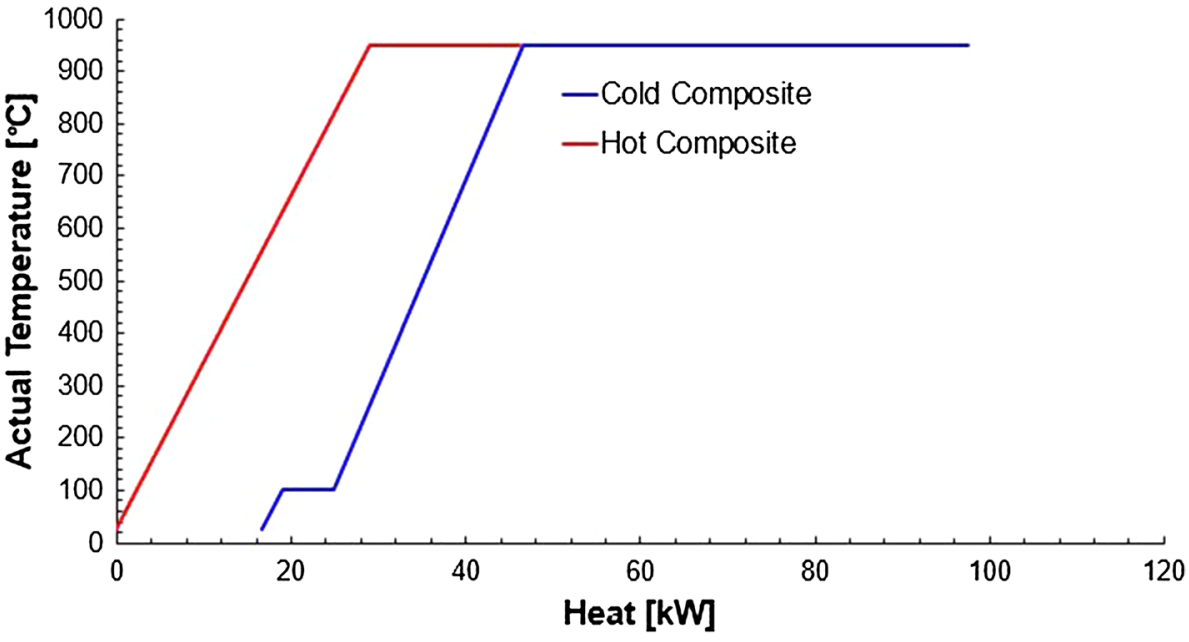

the primary aim of the reduction reactor to produce syngas, methane to $\mathrm{CeO}_{2}$ feeding ratio of $0.7-0.8$ at a temperature of $900{ }^{\circ} \mathrm{C}$ was obtained as the most suitable condition, resulting in a complete reduction of $\mathrm{CeO}_{2}$ to $\mathrm{Ce}_{2} \mathrm{O}_{3}$ while avoiding the formation of $\mathrm{CO}_{2}$ and carbon deposition. The temperature and composition of waste gas (a mixture of $\mathrm{CO}_{2}$ and $\mathrm{H}_{2} \mathrm{O}$ ), coupled with the end use of produced syngas, would govern the operating conditions of the oxidation reactor. However, water splitting reaction peaks at temperatures between 600 and $650{ }^{\circ} \mathrm{C}$, while a monotonic increase of $\mathrm{CO}$ production with the temperature was obtained for $\mathrm{CO}_{2}$ splitting reaction. A minimum molar flow of $0.75 \mathrm{kmol} / \mathrm{h}$ of waste gas at the equimolar composition of $\mathrm{CO}_{2}$ and $\mathrm{H}_{2} \mathrm{O}$ would be required to oxidize a flow of $0.5 \mathrm{kmol} / \mathrm{h} \mathrm{Ce}_{2} \mathrm{O}_{3}$ completely to $\mathrm{CeO}_{2}$ to close the redox cycle. This corresponds to a flow of $50 \%$ excess than the stoichiometric quantity. Further, the system efficiency was evaluated based on two defined efficiency terms for the chemical looping configuration. It is observed that the variations of the flow of waste gas (a mixture of $\mathrm{CO}_{2}$ and $\mathrm{H}_{2} \mathrm{O}$ ), as well as the composition, had little or no impact on the overall system efficiency. Nevertheless, for lower flows of methane, high system efficiency was obtained, however with lower yields of $\mathrm{H}_{2}$ and $\mathrm{CO}$. A system efficiency of around $62 \%$, considering syngas from both the reactors, with a production of syngas composed by $60 \% \mathrm{H}_{2}$ and $40 \%$ $\mathrm{CO}$ was obtained for an isothermal operation at $900{ }^{\circ} \mathrm{C}$ or higher, as the optimum for the entire chemical looping cycle. However, the value drops to $16 \%$ while considering only the syngas from splitting of $\mathrm{CO}_{2}$ and $\mathrm{H}_{2} \mathrm{O}$. The corresponding isothermal system temperature needs to be $900{ }^{\circ} \mathrm{C}$ between the reduction and oxidation reactor. In the end, it can be concluded that these results can be taken as a limiting basis for future experimental and theoretical studies in determining the extent of reactions with non-catalytic ceria-based chemical looping $\mathrm{CO}_{2}$ and $\mathrm{H}_{2} \mathrm{O}$ splitting with methane reduction to evaluate the proposed technology.
Open Access This article is distributed under the terms of the Creative Commons Attribution 4.0 International License (http://creativeco mmons.org/licenses/by/4.0/), which permits unrestricted use, distribution, and reproduction in any medium, provided you give appropriate credit to the original author(s) and the source, provide a link to the Creative Commons license, and indicate if changes were made.

\section{References}

1. Ackermann, S., Sauvin, L., Castiglioni, R., Rupp, J.L.M., Scheffe, J.R., Steinfeld, A.: Kinetics of $\mathrm{CO}_{2}$ reduction over nonstoichiometric ceria. J. Phys. Chem. C 119(29), 16452-16461 (2015). https://doi.org/10.1021/acs.jpcc.5b03464

2. Agrafiotis, C., Roeb, M., Sattler, C.: A review on solar thermal syngas production via redox pair-based water/carbon dioxide splitting thermochemical cycles. Renew. Sustain. Energy Rev. 42, 254-285 (2015). https://doi.org/10.1016/j.rser.2014.09.039

3. Alonso, E., Romero, M.: Review of experimental investigation on directly irradiated particles solar reactors. Renew. Sustain. Energy Rev. 41, 53-67 (2015). https://doi.org/10.1016/j.rser.2014.08.027

4. Ambrosini, A., Eric N. Coker, Anthony, M., Mark, A., James A.O., James E.M.: Oxide materials for thermochemical $\mathrm{CO}_{2}$ splitting using concentrated solar energy vision : sunshine to petrol (2012)

5. Bader, R., Venstrom, L.J., Davidson, J.H., Lipiński, W.: Thermodynamic Analysis of isothermal redox cycling of ceria for solar fuel production. Energy Fuels 27(9), 5533-5544 (2013). https:// doi.org/10.1021/ef400132d

6. Cheng, C.Y., Kelsall, G.H., Kleiminger, L.: Reduction of $\mathrm{CO}_{2}$ to $\mathrm{CO}$ at $\mathrm{Cu}$-ceria-gadolinia (CGO) cathode in solid oxide electrolyser. J. Appl. Electrochem. 43(11), 1131-1144 (2013). https:// doi.org/10.1007/s10800-013-0566-x

7. Chuayboon, S., Stéphane, A., Sylvain, R.: Syngas production via solar-driven chemical looping methane reforming from redox cycling of ceria porous foam in a volumetric solar reactor. Chem Eng J 2, 56 (2018). https://doi.org/10.1016/j.cej.2018.09.072

8. Chueh, W.C., Falter, C., Abbott, M., Scipio, D., Furler, P., Haile, S.M., Steinfeld, A.: High-flux solar-driven thermochemical dissociation of $\mathrm{CO}_{2}$ and $\mathrm{H}_{2} \mathrm{O}$ using nonstoichiometric ceria. Science 330(6012), 1797-1801 (2010). https://doi.org/10.1126/scien ce. 1197834 
9. Chueh, W.C., Haile, S.M.: A thermochemical study of ceria: exploiting an old material for new modes of energy conversion and $\mathrm{CO}_{2}$ mitigation. Philos. Trans. R. Soc. A: Math. Phys. Eng. Sci. 368(1923), 3269-3294 (2010). https://doi.org/10.1098/ rsta.2010.0114

10. Collins-Martinez, V., Bretado, M.E., Zaragoza, M.M., Gutiérrez, J.S., Ortiz, A.L.: Absorption enhanced reforming of light alcohols (methanol and ethanol) for the production of hydrogen: thermodynamic modeling. Int. J. Hydrogen Energy 38(28), 12539-12553 (2013). https://doi.org/10.1016/j.ijhyd ene.2012.11.146

11. Davenport, T.C., Kemei, M., Ignatowich, M.J., Haile, S.M.: Interplay of material thermodynamics and surface reaction rate on the kinetics of thermochemical hydrogen production. Int. J. Hydrogen Energy 42(27), 16932-16945 (2017). https://doi.org/10.1016/j. ijhydene.2017.05.184

12. Davenport, T.C., Yang, C.K., Christopher, J., Michael, J.: Implications of exceptional material kinetics on thermochemical fuel production rates. Energy Technol 4, 6 (2016). https://doi.org/10.1002/ ente.201500506

13. Daza, Y.A., Kent, R.A., Yung, M.M., Kuhn, J.N.: Carbon dioxide conversion by reverse water-gas shift chemical looping on perovskite-type oxides. Ind. Eng. Chem. Res. 53(14), 5828-5837 (2014). https://doi.org/10.1021/ie5002185

14. Demidov, A.I., Markelov, I.A.: Thermodynamics of interaction of iron oxides and carbon monoxide. Russ. J. Appl. Chem. 84(2), 196-198 (2011). https://doi.org/10.1134/S1070427211020054

15. Diver, R.B., Miller, J.E., Allendorf, M.D., Siegel, N.P., Hogan, R.E.: Solar thermochemical water-splitting ferrite-cycle heat engines. J. Sol. Energy Eng. 130(4), 041001 (2008). https://doi. org/10.1115/1.2969781

16. Ermanoski, I., Siegel, N., Stechel, E.: A new reactor concept for efficient solar-thermochemical fuel production. J. Sol.Energy Eng. 135(3), 31002 (2013). https://doi.org/10.1115/1.4023356

17. Fathi, M., Bjorgum, E., Viig, T., Rokstad, O.A.: Partial oxidation of methane to synthesis gas. Catal. Today 63(2-4), 489-497 (2000). https://doi.org/10.1007/BF00774718

18. Furler, P, Scheffe, J., Marxer, D., Steinfeld, A.: Solar reactors for thermochemical $\mathrm{CO}_{2}$ and $\mathrm{H}_{2} \mathrm{O}$ splitting via metal oxide redox reactions. In SFERA II SUMMER SCHOOL, Odeillo, France, France (2014). https://sfera2.sollab.eu/uploads/images/networking /SFERA SUMMER SCHOOL 2014 - PRESENTATIONS/Solar Reactor Reduction - Philipp FURLER.pdf

19. Furler, P., Scheffe, J., Gorbar, M., Moes, L., Vogt, U., Steinfeld, A.: Solar thermochemical $\mathrm{CO}_{2}$ splitting utilizing a reticulated porous ceria redox system. Energy Fuels 26(11), 7051-7059 (2012). https://doi.org/10.1021/ef3013757

20. Galvita, V., Sundmacher, K.: Hydrogen production from methane by steam reforming in a periodically operated two-layer catalytic reactor. Appl. Catal. A 289(2), 121-127 (2005). https://doi. org/10.1016/j.apcata.2005.04.053

21. Gokon, N., Toshinori, S., Tatsuya, K.: Oxygen and hydrogen productivities and repeatable reactivity of $30-\mathrm{Mol} \%-\mathrm{Fe}-$, Co-, Ni-, Mn-doped $\mathrm{CeO}_{2}-\Delta$ for thermochemical two-step water-splitting cycle. Energy 90, 1280-1289 (2015). https://doi.org/10.1016/j. energy.2015.06.085

22. Hartley, U.W., Ngoenthong, N., Cheenkachorn, K., Sornchamni, T.: $\mathrm{CO}_{2}$ to syngas: metal oxides on stainless steel $316 \mathrm{~L}$ for micro-channel reactor application. In: International Conference on Chemical and Biochemical Engineering Paris (France), 20-22 July 2015, 8-11 (2015). https://www.researchgate.net/ profile/Mahdi_Belguidoum/publication/289540155_AbstractsB ook_ICCBE2015/links/5690232b08aec14fa557e115/AbstractsB ook-ICCBE2015.pdf

23. Ji, H.I., Davenport, T.C., Gopal, C.B., Haile, S.M.: Extreme high temperature redox kinetics in ceria: exploration of the transition from gas-phase to material-kinetic limitations. Phys. Chem. Chem. Phys. 18(31), 21554-21561 (2016). https://doi. org/10.1039/c6cp01935h

24. Ji, H.I., Davenport, T.C., Ignatowich, M.J., Haile, S.M.: Gas-phase vs. material-kinetic limits on the redox response of nonstoichiometric oxides. Phys. Chem. Chem. Phys. 19(10), 7420-7430 (2017). https://doi.org/10.1039/c7cp00449d

25. Jiang, Q., Chen, Z., Tong, J., Yang, M., Jiang, Z., Li, C.: Catalytic function of iroxin the two-step thermochemical $\mathrm{CO}_{2}$-splitting reaction at high temperatures. ACS Catal. 6(2), 1172-1180 (2016). https://doi.org/10.1021/acscatal.5b01774

26. Kang, K.S., Kim, C.H., Bae, K.K., Cho, W.C., Kim, S.H., Park, C.S.: Oxygen-carrier selection and thermal analysis of the chemical-looping process for hydrogen production. Int. J. Hydrogen Energy 35(22), 12246-12254 (2010). https://doi.org/10.1016/j. ijhydene.2010.08.043

27. Krenzke, P.T., Davidson, J.H.: Thermodynamic analysis of syngas production via the solar thermochemical cerium oxide redox cycle with methane-driven reduction. Energy Fuels 28(6), 4088-4095 (2014). https://doi.org/10.1021/ef500610n

28. Laachir, A., Perrichon, V., Badri, A., Lamotte, J., Catherine, E., Lavalley, J.C., El Fallah, J., et al.: Reduction of $\mathrm{CeO}_{2}$ by hydrogen. J. Chem. Soc., Faraday Trans. 87(10), 1601-1609 (1991)

29. Lapp, J., Davidson, J.H., Lipiński, W.: Heat Transfer analysis of a solid-solid heat recuperation system for solar-driven nonstoichiometric redox cycles. J. Sol. Energy Eng. 135(3), 031004 (2013). https://doi.org/10.1115/1.4023357

30. Leung, D.Y.C., Giorgio, C., Mercedes Maroto-Valer, M.: An overview of current status of carbon dioxide capture and storage technologies. Renew. Sustain. Energy Rev. 39, 426-443 (2014). https://doi.org/10.1016/j.rser.2014.07.093

31. Li, K., Wang, H., Wei, Y.: Syngas generation from methane using a chemical-looping concept: a review of oxygen carriers. J. Chem. 1, 20 (2013). https://doi.org/10.1155/2013/294817

32. Liu, F.: Cerium oxide promoted oxygen carrier development and scale modeling study for chemical looping comustion. University of Kentucky (2013). https://uknowledge.uky.edu/cgi/viewconten t.cgi?article $=1029 \&$ context $=$ me_etds

33. Lorentzou, S., Karagiannakis, G., Dimitrakis, D., Pagkoura, C., Zygogianni, A., Konstandopoulos, A.G.: Thermochemical redox cycles over Ce-based oxides. Energy Procedia 69, 1800-1809 (2015). https://doi.org/10.1016/j.egypro.2015.03.152

34. Monazam, E.R., Breault, R.W., Siriwardane, R.: Kinetics of magnetite $(\mathrm{Fe} 3 \mathrm{O} 4)$ oxidation to hematite $\left(\mathrm{Fe}_{2} \mathrm{O}_{3}\right)$ in air for chemical looping combustion. Ind. Eng. Chem. Res. 53(34), 13320-13328 (2014). https://doi.org/10.1021/ie501536s

35. Montini, T., Melchionna, M., Monai, M., Fornasiero, P.: Fundamentals and catalytic applications of $\mathrm{CeO}_{2}$-based materials. Chem. Rev. 116(10), 5987-6041 (2016). https://doi.org/10.1021/ acs.chemrev.5b00603

36. Nair, M.M., Abanades, S.: Tailoring hybrid nonstoichiometric ceria redox cycle for combined solar methane reforming and thermochemical conversion of $\mathrm{H}_{2} \mathrm{O} / \mathrm{CO}_{2}$. Energy Fuels 30(7), 6050-6058 (2016). https://doi.org/10.1021/acs.energyfuels.6b010 63

37. Otsuka, K., Wang, Y., Nakamura, M.: Direct conversion of methane to synthesis gas through gas-solid reaction using $\mathrm{CeO}_{2}-\mathrm{ZrO}_{2}$ solid solution at moderate temperature. Appl. Catal. A 183(2), 317-324 (1999). https://doi.org/10.1016/S0926-860X(99)00070 $-8$

38. Otsuka, K., Wang, Y., Sunada, E., Yamanaka, I.: Direct partial oxidation of methane to synthesis gas by cerium oxide. J. Catal. 175(2), 152-160 (1998). https://doi.org/10.1006/jcat.1998.1985

39. Rihko-Struckmann, L.K., Datta, P., Wenzel, M., Kai Sundmacher, N.V.R.A., Dharanipragada, H.P., Galvita, V.V., Marin, G.B.: Hydrogen and carbon monoxide production by chemical looping 
over iron-aluminium oxides. Energy Technology 4(2), 304-313 (2016). https://doi.org/10.1002/ente.201500231

40. Roeb, M., Sattler, C., Klüser, R., Monnerie, N., de Oliveira, L., Konstandopoulos, A.G., Agrafiotis, C., et al.: Solar hydrogen production by a two-step cycle based on mixed iron oxides. J. Sol. Energy Eng. 128(2), 125 (2006). https://doi.org/10.1115/1.21838 04

41. Scheffe, J.R., Welte, M., Steinfeld, A.: Thermal reduction of ceria within an aerosol reactor for $\mathrm{H}_{2} \mathrm{O}$ and $\mathrm{CO}_{2}$ splitting. Ind. Eng. Chem. Res. 53(6), 2175-2182 (2014). https://doi.org/10.1021/ ie $402620 \mathrm{k}$

42. Scheffe, J.R., Steinfeld, A.: Oxygen exchange materials for solar thermochemical splitting of $\mathrm{H}_{2} \mathrm{O}$ and $\mathrm{CO}_{2}$ : a review. Mater. Today 17(7), 341-348 (2014). https://doi.org/10.1016/j.matto d.2014.04.025

43. Smestad, G.P., Steinfeld, A.: Review: photochemical and thermochemical production of solar fuels from $\mathrm{H}_{2} \mathrm{O}$ and $\mathrm{CO}_{2}$ using metal oxide catalysts. Ind. Eng. Chem. Res. 51, 11828-11840 (2012). https://doi.org/10.1021/ie3007962

44. Stamatiou, A., Loutzenhiser, P.G., Steinfeld, A.: Solar syngas production via $\mathrm{H}_{2} \mathrm{O} / \mathrm{CO}_{2}$-splitting thermochemical cycles with $\mathrm{Zn} / \mathrm{ZnO}$ and $\mathrm{FeO} / \mathrm{Fe}_{3} \mathrm{O}_{4}$ redox reactions $\dagger$. Chem. Mater. 22(3), 851-859 (2010). https://doi.org/10.1021/cm9016529

45. Steinfeld, A., Scherrer, P., Kuhn, P., Karni, J.: High-temperature solar thermochemistry: production of iron and synthesis gas by Fe304-reduction with methane. Energy 18(3), 239-249 (1993)

46. Steinfeld, A.: Solar thermochemical production of hydrogena review. Sol. Energy 78(5), 603-615 (2005). https://doi. org/10.1016/j.solener.2003.12.012

47. Takacs, M., Ackermann, S., Alexander Bonk, M., Puttkamer, N.-V., Haueter, P., Scheffe, J.R., Vogt, U., Steinfeld, A.: Splitting $\mathrm{CO}_{2}$ with a ceria-based redox cycle in a solardriven thermogravimetric analyzer. AIChE J. 63(4), 1263-1271 (2017)

48. Tescari, S., Agrafiotis, C., Breuer, S., De Oliveira, L., NeisesVon Puttkamer, M., Roeb, M., Sattler, C.: Thermochemical solar energy storage via redox oxides: materials and reactor/heat exchanger concepts. Energy Procedia 49, 1034-1043 (2013). https ://doi.org/10.1016/j.egypro.2014.03.111

49. Tong, J., Jiang, Q., Chen, Z., Jiang, Z., Li, C.: Two-step thermochemical cycles for $\mathrm{CO}_{2}$ splitting on $\mathrm{Zr}$-doped cobalt ferrite supported on silica. Solar Energy 116, 133-143 (2015). https:// doi.org/10.1016/j.solener.2015.04.007
50. Tuller, H.L.: Solar to fuels conversion technologies: a perspective. Mater. Renew. Sustain. Energy 6(1), 1-16 (2017). https:// doi.org/10.1007/s40243-017-0088-2

51. Venstrom, L.J., Petkovich, N., Rudisill, S., Stein, A., Davidson, J.H.: The effects of morphology on the oxidation of ceria by water and carbon dioxide. J. Sol. Energy Eng. 134(1), 011005 (2012). https://doi.org/10.1115/1.4005119

52. Venstrom, L.J., De Smith, R.M., Hao, Y., Haile, S.M., Davidson, J.H.: Efficient splitting of $\mathrm{CO}_{2}$ in an isothermal redox cycle based on ceria. Energy Fuels 28(4), 2732-2742 (2014). https:// doi.org/10.1021/ef402492e

53. Warren, K.J., Reim, J., Randhir, K., Greek, B., Carrillo, R., Hahn, D.W., Scheffe, J.R.: Theoretical and experimental investigation of solar methane reforming through the nonstoichiometric ceria redox cycle. Energy Technol. 5(11), 2138-2149 (2017). https:// doi.org/10.1002/ente.201700083

54. Warren, K.J., Scheffe, J.R.: Kinetic insights into the reduction of ceria facilitated via the partial oxidation of methane. Mater. Today Energy 9, 39-48 (2018). https://doi.org/10.1016/j.mtene r.2018.05.001

55. Wei, B.: A novel solar-driven system for two-step conversion of $\mathrm{CO}_{2}$ with ceria-based catalysts. KTH Royal Institute of Technology, Stockholm (2014)

56. Welte, M., Barhoumi, R., Zbinden, A., Scheffe, J.R., Steinfeld, A.: Experimental demonstration of the thermochemical reduction of ceria in a solar aerosol reactor. Ind. Eng. Chem. Res. 55(40), 10618-10625 (2016). https://doi.org/10.1021/acs.iecr.6b02853

57. Welte, M., Warren, K., Scheffe, J.R., Steinfeld, A.: combined ceria reduction and methane reforming in a solar-driven particle-transport reactor. Ind. Eng. Chem. Res. 56(37), 10300-10308 (2017). https://doi.org/10.1021/acs.iecr.7b02738

58. Yadav, D., Banerjee, R.: A review of solar thermochemical processes. Renew. Sustain. Energy Rev. 54, 497-532 (2016). https:// doi.org/10.1016/j.rser.2015.10.026

59. Zhou, Y., Rahman, M.N.: Effect of redox reaction on the sintering behavior of cerium oxide. Acta Materialia 45(9):3635-39 (1997). http://bdm.unb.br/bitstream/10483/4095/2/2011_RicardoOliveira MonteiroLopes.pdf

Publisher's Note Springer Nature remains neutral with regard to jurisdictional claims in published maps and institutional affiliations. 